\title{
Assessment of human health risks associated with heavy metals accumulation in the freshwater fish Pangasianodon hypophthalmus in Bangladesh
}

\section{Md Abdullah-hil Maruf}

University of Dhaka Faculty of Biological Sciences

Nusrat Jahan Punom

University of Dhaka Faculty of Biological Sciences

\section{Badhan Saha}

Bangladesh Council of Scientific and Industrial Research

\section{Mohammad Moniruzzaman}

Bangladesh Council of Scientific and Industrial Research

\section{Priyanka Dey Suchi}

Bangladesh Council of Scientific and Industrial Research

\section{Md. Mostavi Enan Eshik}

University of Dhaka Faculty of Biological Sciences

Mohammad Shamsur Rahman ( $\nabla$ shamsur@du.ac.bd)

University of Dhaka, Bangladesh https://orcid.org/0000-0001-8447-3275

\section{Original Paper}

Keywords: Pangasianodon hypophthalmus, Heavy metals, THQ, Hazard Index, Bioaccumulation

Posted Date: February 25th, 2021

DOl: https://doi.org/10.21203/rs.3.rs-203733/v1

License: (c) (i) This work is licensed under a Creative Commons Attribution 4.0 International License.

Read Full License

Version of Record: A version of this preprint was published at Exposure and Health on March 11th, 2021. See the published version at https://doi.org/10.1007/s12403-021-00387-8. 
1 Assessment of human health risks associated with heavy metals accumulation in the

2 freshwater fish Pangasianodon hypophthalmus in Bangladesh

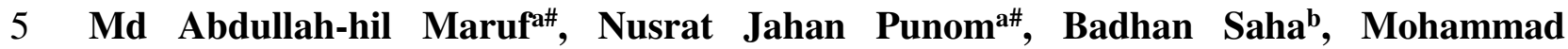
6 Moniruzzaman ${ }^{\text {, }}$, Priyanka Dey Suchi ${ }^{\text {b }}$, Md. Mostavi Enan Eshik ${ }^{\mathbf{a}}$, Mohammad Shamsur $7 \quad \operatorname{Rahman}^{\mathrm{a}, *}$

$9{ }^{a}$ Aquatic Animal Health Group, Department of Fisheries, Faculty of Biological Sciences, 10 University of Dhaka, Dhaka-1000, Bangladesh

$11{ }^{b}$ Biological Research Division, Bangladesh Council for Scientific and Industrial Research 12 (BCSIR), Dhaka 1000, Bangladesh

$15 *$ Corresponding author.

16 E-mail address: shamsur@ du.ac.bd (Mohammad Shamsur Rahman).

17 Tel: +8801818314899 , Fax: +88029667222 (VC office)

18 ORCID: 0000-0001-8447-3275

20 \# Abdullah-hil Maruf and Nusrat Jahan Punom contributed equally to the manuscript 


\section{ABSTRACT}

23 In this study, pangas and feed samples were analyzed to estimate the levels of metallic elements and to profile the human health risks due to consumption of contaminated fish. This investigation confirmed significant variations in heavy metal concentrations among different tissues of pangas in the order of $\mathrm{Ni}>\mathrm{Cu}>\mathrm{Pb}>\mathrm{Cd}>\mathrm{Cr}$ in pre-monsoon; and $\mathrm{Ni}>\mathrm{Cd}=\mathrm{Cu}>\mathrm{Pb}=$ $\mathrm{Cr}$ in post-monsoon. Considerably higher concentrations of $\mathrm{Pb}, \mathrm{Cu}$ and $\mathrm{Cr}$ were estimated in liver; and $\mathrm{Cd}$ and $\mathrm{Ni}$ were detected in muscle than other organs $(p>0.05)$. Statistically significant higher amount of $\mathrm{Cd}, \mathrm{Ni}$, and $\mathrm{Cu}$ were observed in pre-monsoon than post-monsoon. Furthermore, three metal pairs showed significant association $(\mathrm{Pb}-\mathrm{Ni}$ and $\mathrm{Pb}-\mathrm{Cu}$ involved positively; $\mathrm{Cd}-\mathrm{Ni}$ acted negatively). In pre-monsoon, $\mathrm{Cd}, \mathrm{Pb}, \mathrm{Ni}, \mathrm{Cu}$ concentrations of feed significantly differed than pangas contents; whereas only $\mathrm{Cu}$ varied during the post-monsoon. Regression analysis revealed the significant effect of $\mathrm{Ni}$ content in feed on the $\mathrm{Cu}$ deposition of pangas ( $p$-value 0.027 , that was $<0.05)$. For the assessment of potential human health risk of the studied metals, estimated daily intake (EDI), target hazard quotient (THQ), hazard index (HI) and carcinogenic risk (CR) indices were calculated. Studied EDI indicated that an average adult ingested a higher amount of $\mathrm{Ni}$ and $\mathrm{Cu}$ than the recommended intake limit. Nevertheless, only the higher EDI of Ni increases the value of THQ and HI than standard limit indicates adverse non-carcinogenic risk. However, lower $\mathrm{CR}$ of $\mathrm{Pb}$ confirmed no serious health hazard due to the ingestion of pangas. Factor analysis through principal component and cluster analysis suggested that higher concentrations of $\mathrm{Pb}$ and $\mathrm{Ni}$ may regulate by the feed used, geochemical properties or rapid industrialization in the study area. A proper monitoring for controlling the quality of fish feed with sustainable planning for industrialization could secure the booming of pangasius aquaculture in Bangladesh.

\section{Keywords}




\section{Introduction}

Aquatic environment has become polluted with heavy metals day by day which acts

like a global issue of scientific concern, because these metals are indestructible and most of

50 them have toxic effects on organisms (Islam et al., 2017). Literally, heavy metals can be explained as any metal element which contains a comparatively higher density with toxigenic impact on living organism even at a lower exposure dose (Fergusson, 1990; Duffus, 2002). On

the other hand, metal could be considered to be heavy metal which is naturally occurred with $\underline{\text { an atomic number of }>20 \text {, density exceeded } 5 \mathrm{gcm}^{-3} \text { or carried a density relatively greater than }}$ water (Barakat, 2011; Walker et al., 2012, Ali and Khan, 2017). In that sense, cadmium (Cd), lead $(\mathrm{Pb})$, nickel $(\mathrm{Ni})$, chromium $(\mathrm{Cr})$, mercury $(\mathrm{Hg})$, arsenic $(\mathrm{As})$, all of them are listed as the most toxic members of heavy metal (Tchounwou et al., 2012). Actually, the nature of nonbiodegradability, persistence, and bioaccumulation, triggered the metals to show poisonous effects on the health of animal and human (Duman et al., 2007). Heavy metals contamination of aquatic ecosystems is becoming an alarming issue for public health as its potential bioaccumulation mechanism from fish to finally human (Le and Ngo, 2013). Heavy metal contamination in water and its uptake by fishes could be a direct consequence of urban and industrial pollution (Türkmen et al., 2005). Acute and prolonged exposure or contact to metallic elements lead extreme toxicity, renal and hepatopancreatic dysfunction, even carcinogenicity of the brain, prostate gland, and other organs of a human being (Vannoort and Thomson, 2005; Gray et al., 2005; García-Lestón et al., 2010). So far, several criteria of the toxic elements viz. the dose of metal exposure, their route, the chemical properties, along with exposed one's details including age, gender, genetic behaviors, nutritional deficiency, actively regulate the level of toxicity (Tchounwou et al., 2012). Specifically, long-term exposure to Cd contents in high doses could deal with renal dysfunction, osteomalacia, and even increase the vulnerability 
and kidney infection due to Pd exposure for an extended period (García-Lestón et al., 2010). The higher concentration of $\mathrm{Cu}$ in fish indicated these values could increase the chances of adverse risks of kidney and liver damage (Ikem and Egiebor, 2005).

Ingestion of metal elements through dietary substance could be a direct exposure route for the majority of the people (Loutfy et al., 2006). In the aquatic food chain, fishes ranked on the top and hence accumulated a significant amount of metals (Hodson, 1988) that contributed as the cause of toxic metal contamination for consumers. Generally, in any locality, fish consumed as a cheaper and the best supplier of protein and polyunsaturated fatty acids (PUFA). American Heart Association (AHA) suggested intake of fish two times in a week to the fullygrown person that help to control the history of heart attack and stroke (Stone, 1996).

Like other species of fish, cultured striped catfish Pangasianodon hypophthalmus (locally known as 'Pangas' in Bangladesh) offers easy digestibility of protein with low-fat substance (Økland et al., 2005; Orban et al., 2008). However, in the last two decades, Bangladesh has experienced the overgrowing establishment of urbanization and industrialization (Siddiqy, 2017). Literature confirmed the origin of metal contamination in an aquaculture system, including untreated industrial and agricultural dumping in the natural water resources (Zhang et al., 2010; Islam et al., 2018), air pollution (EMEP, 2015), aquatic environment pollution through washout of monsoon or for flooding (Islam et al., 2018), erosion, atmospheric accumulation in the aqueous ecosystem (Baki et al., 2018) and natural 91 geochemical characteristics (Islam et al., 2018). This situation extensively controls the increased nature of toxic metals on fish or pangas. Eating fish (pangas) with deposited toxic elements could enhance the highly critical health issues of a human being (Mansour et al., 2009).

Several works have been published on bioaccumulation of heavy metals in pangas all 96 over the world (Elnimr, 2011; Hossain et al., 2016; Duarte et al., 2019; Milenkovic et al., 2019). 
97 This is a concerning issue as it is directly related to human health when it crosses the acceptable limit. For fish feed, FAO/WHO (1984), EC (2003), WHO (1985) and for pangas, MOFL (2014), FAO/WHO (1989), USFDA (1993), WHO (2011) have published minimum acceptable

100 level for each metal (like $\mathrm{Cd}, \mathrm{Pb}, \mathrm{Ni}, \mathrm{Cu}, \mathrm{Cr}$, and others).

Muktagacha, Trishal, and Bhaluka sub-districts of Mymensingh district are the familiar 102 commercial freshwater fish farming zone of Bangladesh, especially for pangas farming. 103 Geological features of this district have a remarkable blessing of nature, including suitable water sources, average annual rainfall, and better water quality parameters (Ahmed, 2009; FAO, 2000). These criteria strongly have influenced on the introduction of highly active and economically significant aquaculture business. Therefore, fish produced in the farms of Mymensingh, specifically in the sub-districts viz. Trishal, Mymensingh Sadar, Fulpur, Bhaluka, and Muktagacha have been circulated throughout Bangladesh. Unfortunately, in a couple of years, rapidly growing industrialization immensely influence the environmental pollution of the area where all the factories discharge their untreated effluents directly into the

111 canals and then the dumping spread over agricultural lands. Furthermore, several studies 112 reported on heavy contamination of metals ( $\mathrm{As}, \mathrm{Zn}, \mathrm{Cr}, \mathrm{Cd}, \mathrm{Pb}, \mathrm{Sr}, \mathrm{Ni}, \mathrm{Li}, \mathrm{Ag}, \mathrm{Hg}, \mathrm{Co}$, and $\mathrm{Se}$ ) 113 in the dumping grounds of almost 300 different industries distributed in Mymensingh district 114 where every day a significant amount of textile dyes, plastics, metal fabricates, diesel, leather 115 tanners are being discharged into the local agricultural areas (Islam et al., 2015; Ahmed et al., 116 2012; Al Zabir et al., 2016). However, metal contamination of marketed or farmed fish and 117 their diets of Mymensingh has already been examined (Hossain et al., 2016; Al Zabir et al., 118 2016; Akter et al., 2020), but no systematic comparison of metal contents in pangas and their 119 feeds with the seasonal variation reported yet. In Bangladesh, pangas has been included in a 120 regular diet of mass people, especially in a low-income section of the society; it is a highly 121 concerning issue where those consumers could be a target group of potential health hazards 
122 due to the biomagnification of toxic elements in the food chain. Therefore, this research work

123 was aimed to quantify the accumulation of the metals in pangas and fish feed during pre- and

124 post-monsoon, collected from three economically important aquaculture locations of

125 Mymensingh region. Besides, estimation of the potential human health risk because of the

126 ingestion of contaminated pangas, was another substantial objective of the present

127 investigation.

\section{2. Materials and methods}

\subsection{Sampling area}

130

In this study, fish feed and fish samples were purchased from Muktagacha

$131 \quad\left(24^{\circ} 45^{\prime} 57.66^{\prime \prime} \mathrm{N}\right.$ to $\left.90^{\circ} 15^{\prime} 22.09^{\prime \prime} \mathrm{E}\right)$, Trishal $\left(24^{\circ} 34^{\prime} 53.97^{\prime \prime} \mathrm{N}\right.$ to $\left.90^{\circ} 23^{\prime} 41.46^{\prime \prime} \mathrm{E}\right)$ and Bhaluka

$132\left(24^{\circ} 24^{\prime} 28.54^{\prime \prime} \mathrm{N}\right.$ to $\left.90^{\circ} 23^{\prime} 11.79^{\prime \prime} \mathrm{E}\right)$ region of Mymensingh district (Fig. 1). The abundance of

133 fish farms in these areas is praiseworthy. Pangas ( $P$. hypophthalmus) is cultured on a large

134 scale in that area. Household effluents, feed, industrial pollution, and consequently heavy metal

135 released into water bodies of study areas can bio-accumulate in pangas and could transfer into

136 the food chain. The feed that was used to fed pangas was collected from farms of Muktagacha,

137 Trishal, and Bhaluka for this study.

\subsection{Fish feed and pangas sampling}

139 During pre-monsoon and post-monsoon of 2017 , fish feed and pangas samples were

140 collected from three regions of Mymensingh district. In pre-monsoon, a total of 27 adult

141 freshwater pangas (P. hypophthalmus) ranged between 900-1200 g in weight were collected

142 from nine pangas farms (three fish from each farm) and used fish feeds as well from all farms.

143 Whereas in post-monsoon, a total of nine adult pangas were collected from nine pangas farms

144 (one fish from each farm). All fishes were washed with deionized-distilled water, took in sterile 
145 plastic bags, and stored frozen in an icebox. Finally, three organs of pangas (gill, liver and

146 muscle) were dissected and taken for the further preparation. However, in post-monsoon, each

147 organ sample (viz. a gill/ liver/ muscle) of three farms of each sampling site were pooled and 148 considered as a representative organ sample (viz. a gill/ liver/ muscle) for each region. Before 149 digestion, all organ and feed samples were dried at $60^{\circ} \mathrm{C}$ for 48 hours and ground them 150 completely.

\subsection{Chemicals and reagents}

Throughout this study, all reagents and solutions were used with analytical grade

153 (Merck, India). Digestion was maintained with deionized double distilled water, 68\% nitric 154 acid $\left(\mathrm{HNO}_{3}\right)$ and $70 \%$ perchloric acid $\left(\mathrm{HClO}_{4}\right)$. Atomic absorption spectrometer (AA-7000,

155 Shimadzu, Japan) equipped with a single element hollow cathode lamp was used for the determination of five heavy metals $(\mathrm{Cd}, \mathrm{Pb}, \mathrm{Ni}, \mathrm{Cu}$, and $\mathrm{Cr})$. In this process, fish samples were dried in a hot air oven where digestion done by a fume hood (EFD-481, ESCO, USA). For this experiment, all operating parameters which considered for the quantification of each metal and their recovery percentages listed in table 1 . Calibration graph of the correlation coefficient of

160 respective elements were prepared to calculate standard deviation. The accuracy of data was validated for all the elements by certified reference material supplied by Sigma-Aldrich, Germany. To assure the accuracy, sensitivity and precision of the analytical procedure of AAS, SRM 2976-Mussel tissue was analyzed as certified reference material from the national

164 institute of standards (NIST). The limits of detection (LOD) of AAS system for $\mathrm{Cd}, \mathrm{Pb}, \mathrm{Ni}$,

$165 \mathrm{Cu}$, and $\mathrm{Cr}$ were $0.003,0.01,0.02,0.01,0.01 \mathrm{ppm}$, respectively.

\subsection{Assessment of heavy metals}

To estimate metal accumulation in the studied samples, $0.5 \mathrm{~g}$ of dried samples were mixed in $10 \mathrm{ml} \mathrm{HNO}_{3}$ with blank which kept aside for overnight due to analyze the presence 
169 of contamination in the sample before digestion. During digestion, the mixture was digested, 170 grinded for $2 \mathrm{hrs}$ and reheated for $60^{\circ}-80^{\circ} \mathrm{C}$, until the mixture turns to gel. This gel was cooled 171 in $5-10$ mins, then $5 \mathrm{ml} \mathrm{HClO}_{4}$ in each sample was added and digested one more time. After

172 that, the cooled gel solution was filtered and made $25 \mathrm{ml}$ solution with distilled water, that kept 173 in the marked plastic bottle. The total digestion procedure followed the methodology developed 174 by Huq and Alam (2005). Concentrations of metal elements were quantified as mg/kg dry weight for tissues. The following formula developed by Huq and Alam (2005) was considered to determine metals concentration. So, studied metals concentration was calculated by following formula: Concentration of heavy metals $=($ Reading - Blank reading $) \times$ PDF $\times$ SDF;

178 Where, primary dilution factor $(\mathrm{PDF})=$ volume/ weight of sample and secondary dilution

179 factor $(\mathrm{SDF})=$ secondary volume/ secondary weight of sample.

\subsection{Measurement of human health risk}

\subsubsection{Estimated Daily Intake (EDI)}

Estimated daily intake (EDI) of studied metals in pangas was measured by using a metal concentration in pangas, average daily consumption of an adult, and average body weight. The equation described by Shaheen et al. (2016) was followed for EDI quantification. Estimated daily intake $(E D I)=\frac{\text { FIR } \times \mathrm{C}}{\mathrm{BW}}$ where, FIR $=$ Fish/Pangas ingestion rate; on average an adult FIR is $49.5 \mathrm{~g} /$ person/day (BBS, 2015); $\mathrm{C}=$ Heavy metal concentration in pangas $(\mathrm{mg} / \mathrm{kg}$, dry weight $) ; \mathrm{BW}=$ Average body weight $(60 \mathrm{~kg})$.

\subsubsection{Target hazard quotient}

190 heavy metals exposure. As the explanation of USEPA (1989), amount of metals consumption and their absorbed dose is similar which not affected by cooking. This research work assessed; 
192 the non-carcinogenic health risks that related to the intake of pangas by the adult fish consumers

193 based on the target hazard quotients (THQs). THQ values were calculated using the USEPA

194 standard assumption. Equation for the count of THQ $=\frac{E F r \times E D \times F I R \times C}{R f D \times B W \times A T} \times 10^{-3}$ where THQ is

195 the target hazard quotient, $\mathrm{EFr}=$ Exposure frequency ( 365 days/year), $\mathrm{ED}=$ Exposure duration

196 (70 years), FIR $=$ Fish/Pangas ingestion rate (on average adult consumption rate 49.5

$197 \mathrm{~g} /$ person/day), $\mathrm{C}=$ Heavy metal concentration in pangas $(\mathrm{mg} / \mathrm{kg}), \mathrm{BW}=$ Average body weight

198 (60 kg), AT = average exposure time for non-carcinogens (EFr×ED) (365 days/year for 70

199 years), $\mathrm{RfD}=$ The oral reference doses were $0.001,0.0035,0.02,0.04$ and $1.5 \mathrm{mg} / \mathrm{kg} / \mathrm{day}$ for

$200 \mathrm{Cd}, \mathrm{Pb}, \mathrm{Ni}, \mathrm{Cu}$, and $\mathrm{Cr}$, respectively (USEPA, 2020).

201

Hazard index (HI) is a mathematical calculation where all the THQ values of the studied

202 fish added together, and this value reflects the effect of non-carcinogenic risk. So, the equation

203 for $\mathrm{HI}=$ THQ $(\mathrm{Cd})+$ THQ $(\mathrm{Pb})+$ THQ $(\mathrm{Ni})+$ THQ $(\mathrm{Cu})+\mathrm{THQ}(\mathrm{Cr})$. The value of $\mathrm{HI}>10$,

204 in that situation, the higher non-carcinogenic risk is considered for the exposure group of

205 people (USEPA, 2011).

\subsubsection{Carcinogenic risk $(C R)$ analysis}

According to USEPA (1989), carcinogenic health risks were quantified as the probable

raise of a metal that developing cancer over a long-time contamination to that potential carcinogen. Carcinogenic risk $(\mathrm{CR})$ determined by considering the following equation, $\mathrm{CR}=$

$210 \frac{E F r \times E D \times F I R \times C \times C S F}{B W \times A T} \times 10^{-3}$, where, CSF is the oral carcinogenic slope factor and $\mathrm{CSF}$ of $\mathrm{Pb}$ is

$2118.5 \times 10^{-3}(\mathrm{mg} / \mathrm{kg} / \mathrm{day})^{-1}(\mathrm{CEPA}, 2009)$. As USEPA (2010), the safe range of CR placed in $10^{-}$

$212{ }^{4}$ to $10^{-6}$, which means when the CR goes to more than $10^{-4}$, that could increase the chance of

213 carcinogenic risk impact.

214 2.6. Statistical analysis 
216 USA), and the graphs were prepared using MS Excel 2019. Violin plot was made by GraphPad

217 Prism version 8.4.2. The data was presented here as mean \pm SEM (due to the lack of replications

218 in post-monsoon samples, standard deviation used with mean). Multiple comparisons with a

$2195 \%$ level of significance were applied for Tukey's post-hoc tests (ANOVA, $p<0.05$ ) and one-

220 way ANOVA for the multivariate analysis. Multiple linear regression analysis used to

221 determine the effect of the feed elements on the metal contents of pangas (Alizada et al., 2020).

222 Effects testing were completed at a 5\% level of significance, where season and location-based

223 effects not considered. Paired sample t-test was performed ( $t$-test, $p<0.05)$ to find out any

224 impact on the heavy metal concentrations due to seasonal changes. 2-tailed Mann-Whitney U-

225 test $(p<0.05)$ was done to validate the relationship between metals seasonal variations in each

226 sampling area. Bivariate Pearson's correlation test was conducted to check the association

227 among metals in each site.

228 For the factor analysis, the principal component analysis (PCA) was applied to confirm

229 the distribution of the metals, which helped in the identification of the origin of the studied

230 metals (Islam et al., 2018; Milenkovic et al., 2019). Besides, cluster analysis (CA) performed

231 by Ward's linkage method that aided to identify similar distribution group of the metals against

232 different sampling locations (Islam et al. 2018, Milenkovic et al. 2019, Ahmed et al., 2019).

233 All multivariate analyses, like PCA and CA, was performed by JMP version 15.1 (SAS

234 Institute, 2020).

235 3. Results and Discussion

236 3.1. Assessment of metals accumulation in fish

237 3.1.1. Concentration of heavy metals in pangas organs 
Table 2 illustrates the average metal concentrations with SEM of pangas organs in studied sampling sites during pre- and post-monsoon of the year 2017. In pre-monsoon, the order of metals in tissues of pangas was $\mathrm{Ni}>\mathrm{Cu}>\mathrm{Pb}>\mathrm{Cd}>\mathrm{Cr}$. On the other hand, in the postmonsoon, the sequence followed as $\mathrm{Ni}>\mathrm{Cd}=\mathrm{Cu}>\mathrm{Pb}=\mathrm{Cr}$.

During pre-monsoon of 2017, pangas liver of Muktagacha contained the highest amount of cadmium, $\mathrm{Cd}(0.0933 \mathrm{mg} / \mathrm{kg})$ whereas the lowest value of $\mathrm{Cd}$ was recorded in gill sample of Muktagacha and Trishal $(0.03 \mathrm{mg} / \mathrm{kg})$. In contrast, during post-monsoon, the highest concentration of $\mathrm{Cd}$ recorded in the muscle sample of Trishal and lowest in the liver sample of Bhaluka. Table 2 also describes the total concentration of metals present in the pangas of each sampling site. Cd concentration of studied pangas, which brought from each sampling area of Mymensingh district, significantly varied within seasonal changes. Furthermore, for $\mathrm{Cd}$, no significant relation observed among gill, liver, and muscle within each sampling region $(p>0.05)$ in both pre- and post-monsoon.

During pre-monsoon, the highest level of $\mathrm{Pb}$ in pangas gill was observed in Trishal $(0.6517 \mathrm{mg} / \mathrm{kg})$ and the lowest in Muktagacha $(0.11 \mathrm{mg} / \mathrm{kg})$. In the liver, higher concentration was documented in Muktagacha $(2.15 \mathrm{mg} / \mathrm{kg})$ and lower in the Trishal region $(0.0 \mathrm{mg} / \mathrm{kg})$. Whereas, in muscle, the highest level of $\mathrm{Pb}$ was $1.1917 \mathrm{mg} / \mathrm{kg}$ in Trishal and lowest in the farms of Bhaluka $(0.0 \mathrm{mg} / \mathrm{kg})$. This experiment confirmed the significant level of $\mathrm{Pb}$ composition in liver samples of Muktagacha rather than the gill and muscle samples of this region $(p<0.05)$. In the post-monsoon season, the concentration of lead $(\mathrm{Pb})$ in the pangas organ estimated below the detection limit (BDL). At the end, table 2 indicated that pangas of Muktagacha contained more $\mathrm{Pb}$ contents in pre-monsoon time than post-monsoon.

In the pre-monsoon period, the highest and lowest recorded nickel concentration was $102.78 \mathrm{mg} / \mathrm{kg}$ and $22.4367 \mathrm{mg} / \mathrm{kg}$ in muscle samples of Muktagacha and Bhaluka. There were no significant differences found among gill, liver, and muscle within the region $(p>0.05)$ 
263 (Table 2). During post-monsoon, farms of Muktagacha and Trishal showed the decreased value 264 of $\mathrm{Ni}$ concentration in pangas organs and followed the sequence gill $>$ liver=muscle.

265 Nevertheless, in the farms of Bhaluka, the sequence followed as muscle>liver>gill. The 266 average Ni concentration of gill, liver, and muscle of pangas was insignificant within study 267 areas $(p>0.05)$. Additionally, in pre-monsoon, pangas of Trishal carried a significant amount 268 of Ni than samples of Muktagacha and Bhaluka. Even Ni contents of Trishal and Bhaluka 269 showed significantly higher accumulation in the pre-monsoon period than post-monsoon 270 (Table 2).

Copper $(\mathrm{Cu})$ concentration of liver samples of Muktagacha, Trishal, and Bhaluka 272 showed significant variation in comparison to gill and muscle samples, in the pre-monsoon 273 season (Table 2). On the other hand, during post-monsoon, copper accumulation in different organs of Muktagacha was in the order of gill=muscle> liver, whereas in Trishal, the order was muscle> liver> gill and in Bhaluka that was muscle> gill> liver. In the pangas of Muktagacha zone, a higher amount of $\mathrm{Cu}$ concentration was estimated in pre-monsoon than post-monsoon.

277 Besides, no significant variation observed in $\mathrm{Cu}$ values among three sampling sites within each sample collection period (Table 2).

In the pre-monsoon time, the highest recorded concentration of chromium $(\mathrm{Cr})$ in gill was $0.0933 \mathrm{mg} / \mathrm{kg}$ in Trishal, and the lowest value was $0.0 \mathrm{mg} / \mathrm{kg}$ in Muktagacha. In pangas liver, the highest concentration observed in Trishal $(0.1567 \mathrm{mg} / \mathrm{kg})$ and BDL (below detection

282 level) in Muktagacha and Bhaluka. In muscle samples, higher concentration estimated in 283 Muktagacha $(0.0933 \mathrm{mg} / \mathrm{kg})$ and BDL in Bhaluka and Trishal. Moreover, Cr content was nil/ below the detection limit in post-monsoon time. Both pre- and post- monsoon periods, there were no significant differences found among organs within each region $(p>0.05)$. Similarly, pangas of sampling sites do not show any significant relation in seasonal variations (Table 2). 

of FAO/WHO (1989). Even $\mathrm{Pb}$ concentrations in pangas of three locations during pre-monsoon crossed the acceptable limit established by FAO/WHO (1989). A pre-monsoon muscle sample of Trishal contained an extreme amount of Ni that also flips the permissible limit. Also, all tested pre-monsoon liver samples of Mymensingh observed higher values of $\mathrm{Cu}$ contamination, which exceed the standard limit of FAO/WHO (1989). On the other hand, the muscle tissue of Muktagacha, gill, and liver of Trishal composed higher loads of $\mathrm{Cr}$ than the acceptable level of WHO (2011) except in Bhaluka. The standard level of heavy metals in fish prepared by Bangladesh government are as follows- $\mathrm{Cd} \leq 0.25 \mathrm{mg} / \mathrm{kg}, \mathrm{Pb}=0.30 \mathrm{mg} / \mathrm{kg}$, Ni not defined, $\mathrm{Cu}$ $=5 \mathrm{mg} / \mathrm{kg}$ and $\mathrm{Cr}=1 \mathrm{mg} / \mathrm{kg}$ (MOFL, 2014). According to this standard, total Cd contents in pangas during post-monsoon and $\mathrm{Pb}$ and $\mathrm{Cu}$ values exceeded permissible limit. On the contrary, Cr did not surpass this maximum acceptable level.

Several studies were summarized in table 7 those worked on heavy metals contamination in different pangas species. In comparison with the present study, Hossain et al. (2016), Das et al. (2017), Duarte et al. (2019), Milenkovic et al. (2019) and Strungaru et al. (2020) confirmed a high concentration of $\mathrm{Cd}, \mathrm{Pb}, \mathrm{Ni}, \mathrm{Cr}$ in different organs of pangas which exceed the permissible level of intake. Besides, Kamruzzaman et al. (2018) studied the muscle of Pangasius sutchi collected from Messua Bazar of Mymensingh town, Bangladesh, in which the estimated values of $\mathrm{Cd}$ and $\mathrm{Cr}$ were lower than this research work. Another study on Pangasius pangasius muscle sampled from the agro-ecological zones of Bangladesh confirmed the similar lower

307 loads of $\mathrm{Cd}, \mathrm{Pb}, \mathrm{Ni}$, and $\mathrm{Cu}$ except $\mathrm{Cr}$ (Ahmed et al., 2015). On the other hand, higher $\mathrm{Cd}$ and 308 Ni contents $(0.616$ and $231.50 \mathrm{mg} / \mathrm{kg})$ in the liver of Pangasius hypothalmus reported by 309 Hossain et al. (2016), this work validated the present investigation. The fish samples of Hossain 310 et al. were collected from different fish markets of Dhaka city. Liver tissue is one of the 311 indicators of environmental pollution due to the physiological role of this organ, where it acts 
312 as a significant deposition area of metals in the fish body (Henry et al., 2004). Higher copper

313 contamination in liver tissue dealt with by Kim and Kang (2004), this study strongly justifies

314 the situation of this research. In this experiment, the pangas muscle contained a significant

315 amount of Ni rather than other fish tissue; this statement partially supported by Mwakalapa et

316 al. (2019). Ali and Khan (2018) assessing the concentration of $\mathrm{Cr}, \mathrm{Ni}, \mathrm{Cd}$, and $\mathrm{Pb}$ in different

317 freshwater fish species of River Kabul, Pakistan and found the average concentrations of $\mathrm{Cr}$,

$318 \mathrm{Ni}, \mathrm{Cd}$, and $\mathrm{Pb}$ in muscle samples of fish ranged from 12.3 to $33.0,33.2$ to $109.2,0.98$ to 1.5 ,

319 and 13.9 to $29.6 \mathrm{mg} / \mathrm{kg}$ wet weight, respectively.

Research work on three cultured fish species [grass carp (Ctenopharyngodon idella), silver carp (Hypophthalmichthys molitrix) and mrigel (Cirrhinus cirrhosis)] of Muktagacha and Trishal fish farms ensured the higher accumulation of $\mathrm{Cd}(1.127 \mu \mathrm{g} / \mathrm{g}), \mathrm{Pb}(18.98 \mu \mathrm{g} / \mathrm{g})$, $\mathrm{Ni}(0.688 \mu \mathrm{g} / \mathrm{g}), \mathrm{Cu}(15.197 \mu \mathrm{g} / \mathrm{g})$ and $\mathrm{Cr}(15.097 \mu \mathrm{g} / \mathrm{g})$ in the fish samples which quite similar to the present experiment except for loads of $\mathrm{Ni}$ and $\mathrm{Cr}$ (Akter et al., 2020). However, a study to evaluate heavy metals soil pollution in Bhaluka region by $\mathrm{Al}$ Zabir et al. highlighted the devastating condition of that particular zone due to the on-growing industrialization and unplanned urbanization (Al Zabir et al., 2016).

Previous studies indicated several causes behind the excessive value of metals in fish, such as different anthropogenic ingredients (boating, use of antifouling paint, oil dropping,

330 fishing, agrochemicals, etc.), overgrowing unbalance industrialization, natural geochemical 331 properties, etc. (Al Zabir et al., 2016, Islam et al., 2018, Rajeshkumar and Li, 2018, Hossain et al., 2018). Studies on heavy metals accumulation in fish farms pointed the source of contamination could be from sharing one-way waste discharge system of every pond in the

334 farm area, a habitat of the farm, farm ecosystem condition, water quality issues of the farm 335 system, excessive use of growth supplements as feed additives (Ali and Amaal, 2005; Li et al., 336 2010; Nofal et al., 2019). 


\subsubsection{Seasonal comparison of metal contents in pangas of Mymensingh district}

338 Paired sample $t$-test of pre- and post-monsoon pangas sample of three studied areas in 339 Mymensingh district illustrated in fig. 2. This figure showed statistically significant variations

340 between studied seasons in each metal. $\mathrm{Cd}, \mathrm{Ni}$, and $\mathrm{Cu}$ contents were significantly higher in 341 pre-monsoon than post-monsoon (Fig. 2). Additionally, in pre-monsoon of 2017, pangas samples contained a higher value of $\mathrm{Pb}$ (pre-monsoon $=0.72 \pm 0.23$ and post-monsoon= $0.00 \pm 0.00 \mathrm{mg} / \mathrm{kg}$ ), $\mathrm{Ni}$ (pre-monsoon= 48.15 \pm 7.21 and post-monsoon= 2.18 $\pm 1.06 \mathrm{mg} / \mathrm{kg}$ ), $\mathrm{Cu}$

344 (pre-monsoon $=14.61 \pm 3.98$ and post-monsoon $=0.65 \pm 0.04 \mathrm{mg} / \mathrm{kg}$ ), $\mathrm{Cr}$ (pre-monsoon= $3450.04 \pm 0.02$ and post-monsoon $=0.00 \pm 0.00 \mathrm{mg} / \mathrm{kg}$ ) except in the Cd (pre-monsoon $=0.05 \pm 0.01$ 346 and post-monsoon $=0.65 \pm 0.04 \mathrm{mg} / \mathrm{kg}$ ). Figure 2 also defined that total amount of each metal 347 loads in pangas samples of Mymensingh always remained below the acceptable limit. Pal and Maiti (2018) observed the higher concentration of $\mathrm{Cd}, \mathrm{Pb}$, and $\mathrm{Cr}$ during the pre-monsoon season; their findings are consistent with present experiment. Similar observations obtained by

350 Saha et al. (2016) agreed with this investigation where they worked on the pangas sample.

351 Worldwide several studies established seasonal effects on metal deposition in fish (Gu et al., 2017; Rajeshkumar and Li, 2018; Sow et al., 2019; Sunjog et al., 2019. Besides, higher cadmium loads in Panulirus homarus during post-monsoon were also observed by Mahdi Abkener et al. (2018) that has similar situation with this study. In Bangladesh, after the heavy rainfall in monsoon, washout of agricultural effluents, industrial wastages, batteries, alloys directly come to add in the open water supply system that could be a great source of $\mathrm{Cd}$ contamination during post-monsoon period. Association between effluent dumping with potential toxic substance availability into aquatic biota described by Baeyens et al. (1998); Wang and Wang (2016). 

sampling area, which presented in table 3 (A, B, C) with star signs (Pearson's correlation test, 1 and 5\% significance level). During pre-monsoon, only $\mathrm{Pb}(0.83 \mathrm{mg} / \mathrm{kg})$ and $\mathrm{Cu}(12.61 \mathrm{mg} / \mathrm{kg})$ content of Muktagacha pangas were in a strong positive linear association between these metals. On the other hand, the post-monsoon concentration of $\mathrm{Cd}$ and $\mathrm{Cu}$ in every studied site showed an entirely positive linear correlation between them. However, the $p$-value of $\mathrm{Cd}, \mathrm{Pb}$, and $\mathrm{Cu}$ was $<0.05$ in every season; consequently, it could determine that there was a linear association among metals in each sampling site (Table 3-A, B). On the other hand, table 3-C suggests the correlated metals of pangas in Mymensingh districts, and the positively related pairs were like $\mathrm{Pb}-\mathrm{Ni}(0.44), \mathrm{Pb}-\mathrm{Cu}$ (0.36), Ni-Cu (0.146), Ni-Cr (0.025), $\mathrm{Cu}-\mathrm{Cr}$ (0.175), respectively. Besides, three pairs showed significant association where two pairs $(\mathrm{Pb}-\mathrm{Ni}$ and $\mathrm{Pb}-\mathrm{Cu}$ ) positively involved and one negatively (Cd-Ni). Girgis et al. (2019) confirmed a positive association with the level of metallothionein (MT) and loads of $\mathrm{Pb}$ and $\mathrm{Cu}$ across seasonal changes.

\subsection{Analysis of metal accumulation in feed and pangas}

Figure 3A (i-v) represents an average accumulation of $\mathrm{Cd}, \mathrm{Pb}, \mathrm{Ni}, \mathrm{Cu}, \mathrm{Cr}$ in feed and pangas collected from farms of Muktagacha, Trishal, and Bhaluka regions of Mymensingh district during pre-monsoon.

In feed samples, the highest concentration of cadmium $(\mathrm{Cd})$ recorded in Bhaluka $(0.8967 \mathrm{mg} / \mathrm{kg})$ and the lowest in Muktagacha $(0.3767 \mathrm{mg} / \mathrm{kg})$ whereas in pangas samples, the concentration of Cd was highest in Muktagacha $(0.0589 \mathrm{mg} / \mathrm{kg})$ and lowest in Trishal $(0.0372$ $\mathrm{mg} / \mathrm{kg}$ ). Besides, feed and pangas of Muktagacha and Bhaluka contained a significantly higher

383 level of Cd than Trishal ( $p<0.05$, Fig. 3A-i). On the other hand, figure 3A (ii) shows the higher level of lead $(\mathrm{Pb})$ in feed samples of Muktagacha $(0.1867 \mathrm{mg} / \mathrm{kg})$ and BDL in Bhaluka and 
385 Trishal. In pangas, the concentration of $\mathrm{Pb}$ was highest in Muktagacha $(0.8317 \mathrm{mg} / \mathrm{kg})$ and the lowest in Trishal $(0.6145 \mathrm{mg} / \mathrm{kg})$. Similarly, $\mathrm{Pb}$ content in feed and pangas of Muktagacha and

387 Trishal was significantly higher than Bhaluka ( $p<0.05$, Fig. 3A-ii). The highest value of nickel 388 (Ni) recorded in Muktagacha feed sample $(684.30 \mathrm{mg} / \mathrm{kg})$ and lowest concentration found in 389 feed of Bhaluka $(207.27 \mathrm{mg} / \mathrm{kg})$ whereas pangas of Trishal region contained higher amount of $390 \mathrm{Ni}(62.3578 \mathrm{mg} / \mathrm{kg})$ than Muktagacha and Bhaluka $(48.7411 \mathrm{mg} / \mathrm{kg}$ and $33.3467 \mathrm{mg} / \mathrm{kg})$. 391 Nickel concentration in feed and pangas of Muktagacha significantly differed from other studied regions ( $p<0.05$, Fig. 3A-iii). Figure 3A (iv) shows the higher value of copper $(\mathrm{Cu})$ in feed of Bhaluka $(5.88 \mathrm{mg} / \mathrm{kg})$ and the least concentration observed in Muktagacha $(5.18$ $\mathrm{mg} / \mathrm{kg})$. In pangas sample, the concentration of $\mathrm{Cu}$ was highest in Bhaluka $(16.1 \mathrm{mg} / \mathrm{kg})$ and lowest in Muktagacha $(12.6067 \mathrm{mg} / \mathrm{kg}) . \mathrm{Cu}$ contents significantly varied in Trishal, and Bhaluka respect to Muktagacha $(p<0.05$, Fig. 3A-iv). However, chromium concentrations in feed samples were below detection level (BDL) for all sampling sites, whereas pangas samples contained the highest $\mathrm{Cr}$ value in Trishal $(0.0833 \mathrm{mg} / \mathrm{kg})$ and lowest in Bhaluka $(0.0111$ $\mathrm{mg} / \mathrm{kg}$ ). There were no significant differences among feed and pangas within the studied sites ( $p>0.05$, Fig. 3A-v).

401

Figure 3B (i-iv) explains the mean heavy metal composition of $\mathrm{Cd}, \mathrm{Pb}, \mathrm{Ni}, \mathrm{Cu}$ in feed 402 and pangas samples, collected from farms of Muktagacha, Trishal, and Bhaluka of Mymensingh region during post-monsoon.

Figure 3B (i) describes that in Muktagacha, the concentrations of cadmium (Cd) in pangas and their feed were $0.6933 \mathrm{mg} / \mathrm{kg}$ and $0.3769 \mathrm{mg} / \mathrm{kg}$, respectively. Whereas, in Trishal, the accumulation of cadmium in pangas and their feeds were $0.675 \mathrm{mg} / \mathrm{kg}$ and $0.4233 \mathrm{mg} / \mathrm{kg}$, respectively. In Bhaluka, the concentration of $\mathrm{Cd}$ in pangas $(0.5817 \mathrm{mg} / \mathrm{kg})$ was lower than their feed $(0.8967 \mathrm{mg} / \mathrm{kg})$. On the other hand, figure 3B (ii) shows that in Muktagacha, the concentration of lead $(\mathrm{Pb})$ in pangas was BDL, but their feed had $0.1867 \mathrm{mg} / \mathrm{kg}$. No trace of 
$410 \mathrm{~Pb}$ was confirmed in pangas and feed samples, which collected from Trishal and Bhaluka. In

411 Muktagacha, the concentration of $\mathrm{Ni}$ in pangas $(1.2633 \mathrm{mg} / \mathrm{kg})$ was too lower than their feed

412 Ni concentration (684.3 mg/kg) (Fig. 3B, iii). In Trishal, this value was $2.1067 \mathrm{mg} / \mathrm{kg}$ in 413 pangas, which was too lower than their feed concentration $(454.3333 \mathrm{mg} / \mathrm{kg})$. In Bhaluka, the 414 concentration of $\mathrm{Ni}$ in pangas $(2.1067 \mathrm{mg} / \mathrm{kg}))$ was also lower than their feed $(207.27 \mathrm{mg} / \mathrm{kg})$.

415 Figure 3B (i-iii) shows there are no significant differences in $\mathrm{Cd}, \mathrm{Pb}$, and $\mathrm{Ni}$ composition in 416 feed and pangas $(p>0.05)$. Nevertheless, copper concentration significantly varied in all feed 417 and pangas samples of studied areas $(p<0.05)$ (Fig. 3B-iv). $\mathrm{Cu}$ content was lower in the 418 Muktagacha pangas sample $(0.6933 \mathrm{mg} / \mathrm{kg})$ than their feed sample $(5.1883 \mathrm{mg} / \mathrm{kg})$. Also, in 419 Trisha and Bhaluka region, the estimated concentration of $\mathrm{Cu}$ in the pangas feed sample was 420 higher than the pangas sample. In this study, any contamination due to the presence of chromium was not recorded both in feed and pangas of the studied regions during postmonsoon.

Furthermore, this study confirmed the effect of feed metal contents in the variation of metal loads in pangas that attached in table 4. A multiple linear regression model was used to find out the effect and the final regression model for this study was $\mathrm{Y}$ (metals in pangas) $=\alpha$ 426 (intercept of unstandardized co-efficient $)+\beta_{1} \times\left(\mathrm{X}_{1}=\mathrm{Cd}\right.$ in feed $)+\beta_{2} \times\left(\mathrm{X}_{2}=\mathrm{Pb}\right.$ in feed $)+$ $\beta_{3} \times\left(\mathrm{X}_{3}=\mathrm{Ni}\right.$ in feed $)+\beta_{4} \times\left(\mathrm{X}_{4}=\mathrm{Cu}\right.$ in feed $)+\beta_{5} \times\left(\mathrm{X}_{5}=\mathrm{Cr}\right.$ in feed $)$ for the estimation, all the required values are listed in table 4. Among all the relation-establishment testing of feed metal contents on metal accumulation in pangas, only feed contaminated with Ni significantly

430 contributed to the $\mathrm{Cu}$ deposition in pangas ( $p$-value 0.027 , that was $<0.05$ ). Table 4 determined 431 that the estimated $\alpha$ of the tested model was -14.783 , which defines on average the change of $432 \mathrm{Cu}$ in pangas was $14.783 \%$ when the feed sample contained a load variation of $0.009 \% \mathrm{Ni}$. The 433 calculated $\beta$ value of $\mathrm{Ni}$ in the feed sample was 0.009 , which explained the effect of a $1 \%$ 434 change of $\mathrm{Ni}$ loads in feed, could change $0.009 \%$ of the $\mathrm{Cu}$ concentrations in pangas. Besides, 
435 in this situation, $\mathrm{R}^{2}$ was 0.907 that implies $90.7 \%$ of the total variation of $\mathrm{Cu}$ contents in pangas

436 can be explained by the regression model or by the variation of feed with Ni loads (Table 4).

Different works have been done on heavy metals contamination in fish feed samples

(Fallah et al., 2011; Anhwange et al., 2012; Saha et al., 2018, Sabbir et al., 2018; Mo et al., 2019, Ali et al., 2019). In this study, Ni contents of feed samples in the studied locations exceed

440 the permissible levels of EC (2003). Other metal loads positioned below the acceptable limits of FAO/WHO (1984), WHO (1985). The Cd and Cu concentrations of the tested feed found to show similar patterns as described by Saha et al. (2018) (listed in table 8). Lower values of $\mathrm{Pb}$ and $\mathrm{Cr}$ in the studied fish feeds supported by Mo et al. (2019), Anhwange et al. (2012), Fallah et al. (2011). In the manufacturing of fish feed, $\mathrm{Cu}$ is one of the essential growth enhancers used as feed additives, which could be the cause of higher accumulation of copper in pangas 446 (Burridge et al., 1999). The extreme contamination of nickel in the fish feed samples was observed in the present study where this high value may enter the fish feed through the raw materials (Saha et al., 2018).

\subsection{Evaluation of human health risk}

\subsubsection{Estimation of daily intake of metals}

Figure 4 (i-iv) demonstrates the estimated daily intake (EDI) (mg/day) of heavy metals due to their intake by pangas. In 2017, pangas of Mymensingh district followed a descending order for EDI of each metal through the consumption of this fish and the order was Ni (58.2986 $\mathrm{mg} /$ day $)>\mathrm{Cu}(17.1353 \mathrm{mg} /$ day $)>\mathrm{Pb}(1.5813 \mathrm{mg} /$ day $)>\mathrm{Cd}(0.5720 \mathrm{mg} /$ day $)>\mathrm{Cr}(0.1540$ mg/day). Figure 4 (i) present the EDI distribution against studied metal concentrations of Muktagacha, where nickel contents of pangas showed the maximum EDI value of 47.806 $\mathrm{mg}$ /day and minimum $\mathrm{Ni}$ value of $1.0422 \mathrm{mg} /$ day. On the other hand, in that region, the lowest daily consumption of heavy metal of average adults was chromium (max. $0.5720 \mathrm{mg} / \mathrm{day}$ and 
min. nil). Similarly, Trishal and Bhaluka exhibited the same pattern described above.

460 Furthermore, this study confirmed an average adult of Mymensingh ingested a higher amount

461 of $\mathrm{Ni}$ and $\mathrm{Cu}$ in contrast to the recommended intake limit of JECFA (2019) (Fig. 4 i-iv).

462

463

464

465

466

467

468

469

470

471

472

473

474

475

476

477

478

479

480

481

482

\subsubsection{Non-carcinogenic risk estimation}

The boxplots of heavy metals displayed the range of non-carcinogenic risk in fig. 5 (iiv). Through the consumption of pangas of the experimented sites could be the key route of $\mathrm{Ni}$ intake in the body of an adult. The range of THQ of Ni was $0.052-2.915$, in which the THQ value exceeds the acceptable threshold 1 (USEPA, 2011). Besides this, other metals viz. Cd (0.017-0.572), $\mathrm{Pb}($ nil - 0.452), $\mathrm{Cu}(0.012-0.428)$ and $\mathrm{Cr}$ (nil - 1.03E-4) occupied the below acceptable threshold. Overall, the highest Ni THQ recorded in Trishal and lowest in tested pangas of Muktagacha. Therefore, the order of non-carcinogenic risk of tested metals in 2017 was $\mathrm{Ni}>\mathrm{Cd}>\mathrm{Pb}>\mathrm{Cu}>\mathrm{Cr}$. Risk level of $\mathrm{Ni}$ could contribute to the serious concerning issue for residents of Trishal as well for the human health of Mymensingh even in all over Bangladesh. Additionally, the order of HI (Hazard Index) in the sampling areas was $H I_{\text {Trishal }}$ (9.837) $>H I_{\text {Muktagacha }}(8.184)>H I$ Bhaluka (6.375) (Table 5). If we considered the individual sampling sites, no one crosses the acceptable limit of hazard index suggested by literature (Lei et al., 2015; Dadar et al., 2017) and confirmed less non-carcinogenic risk effects due to the ingestion of pangas.

\subsubsection{Carcinogenic risk calculation}

The present study found that the estimated value of lead $(\mathrm{Pb})$, tested from all sites of Mymensingh in pre-monsoon season were between $10^{-4}$ to $10^{-6}$, this posed the tolerable and negligible cancer-causing hazard risk. Figure 6 shows the carcinogenic risk $(\mathrm{CR})$ of $\mathrm{Pb}$ due to the ingestion of pangas of the tested sites. In post-monsoon, the carcinogenic risk (CR) was not estimated because the concentration of $\mathrm{Pb}$ was below the detection limit (BDL). The highest 
$483 \mathrm{CR}$ of $\mathrm{Pb}$ detected from pangas of Muktagacha (0.00384), then Trishal (0.00214), and Bhaluka 484 (0.00156). The descending order of the median $\mathrm{CR}$ of $\mathrm{Pb}$ was Muktagacha (5.832E-06) > 485 Bhaluka (5.03E-06) > Trishal (4.309E-06). According to USEPA (2010), when the CR value 486 lies under $10^{-6}$ that could be considered as negligible risk due to exposure of an average adult 487 but when this condition turns into more than $10^{-4}$ that reach to the serious cancer risk. Figure 6 488 clearly depicted the actual scenario of the studied location and confirm the tolerable health 489 issues due to the consumption of $\mathrm{Pb}$ contained pangas. This situation also supported by (Baki 490 et al., 2018) and Ahmed et al. (2019) where the range of carcinogenic risk value of $\mathrm{Pb}$ was 7.99E-07 to $1.24 \mathrm{E}-05$ and $8.48 \mathrm{E}-08$ to $1.79 \mathrm{E}-05$ in studied fish species collected from Saint

492 Martin Island and Karnaphuli river of Bangladesh. Pal and Maiti (2018) confirmed their 493 estimated $\mathrm{CR}$ of $\mathrm{Pb}$ contents suspended on the acceptable limit in cultured Labeo rohita and 494 Labeo bata. However, Ahmed et al. (2015) worked on Rui (Labeo rohita), Pangas (Pangasius 495 pangasius) and Tilapia (Oreochromis mossambicus) collected from markets of 30 agroecological zones in Bangladesh and found an acceptable carcinogenic value of $\mathrm{Pb}$ which was $3.9 \times 10^{-6}$. This study also agreed with the present investigation.

\subsection{Metal distribution in pangas of Mymensingh region by PCA and cluster analysis}

Figure 7 displays a data reduction method, principal component analysis (PCA) used in this study to identify two principal factors/ components that described $62.18 \%$ of the data variance. PCA analysis extracted two significant components (PC1 and PC2) from the dataset

502 that hold eigenvalues more than 1 (Table 6). Component 1 stood with $40.4 \%$ of the metal values

503 and exhibited the highest eigenvalue of 2.020, which explained that the PC1 shared the highest partition of the total variances in the multivariate dataset. On the other hand, the second-highest percentage of variance defined as PC2 that contains the eigenvalue of 1.088. Besides eigenvalue, drastic changes in the slope of the scree plot (Fig. 7) considered confirming the

507 first two factors represented most of the variances of the dataset. 
From the rotated component matrix and the biplot of fig. 7 depicted the first component,

$509 \mathrm{PC} 1$ shared the highest positive relation with $\mathrm{Pb}(0.787)$ and $\mathrm{Ni}(0.805)$ as well highest negative

510 association with $\mathrm{Cd}$. On the contrary, the second component, PC2, dealt with the maximum

511 association with the contents of $\mathrm{Cu}(0.472)$ and $\mathrm{Cr}(0.910)$. The positively associated PC1 loads

512 of $\mathrm{Pb}$ and $\mathrm{Ni}$ could consider as group1 that ensured their most probable common origin from

513 Trishal. Nevertheless, without any substantial observations, this would not be assumed

514 (Ashaiekh et al., 2019). Higher concentrations of $\mathrm{Pb}$ and $\mathrm{Ni}$ indicate maybe their presence were

515 regulated by the feed used in the respective studied location or by the parameters of the

516 geochemical properties of the area or because of the rapid industrialization in the study area

517 (Hossain et al., 2015; Nguyen et al., 2020) whereas $\mathrm{Cu}$ and $\mathrm{Cr}$ contents could be accumulated

518 from feed supplied in the studied area.

519 The present study also conducted cluster analysis (CA) on the estimated data, which helped to group sampling sites that ensured similar share values across the different estimated metals. In row-wise consideration of fig. 8, cluster 1 exhibited the group of similar concentrations of metals than cluster 2 and so on. Every cluster indicated an individual common dataset among other clusters. The mean concentration of cluster 3 was the highest and lowest mean observed in cluster 1 . In cluster 2, most of the metal concentrations found from two farms of Trishal, whereas in cluster 3, most values come from all three farms of Bhaluka. in each site. Additionally, figure 8 reflects the highest number of variables lay in cluster 3 and

528 lowest in cluster 2. However, farms of Trishal contain the highest concentrations of $\mathrm{Cd}, \mathrm{Ni}$, $529 \mathrm{Cu}$, and $\mathrm{Cr}$ in which the highest load of $\mathrm{Pb}$ observed in one farm of Bhaluka. The rapidly 530 growing industrialization of Bhaluka region indicates an alarming scenario of the polluted 531 environment described by $\mathrm{Al}$ Zabir et al. (2016). $\mathrm{Pb}, \mathrm{Cu}, \mathrm{Cr}$, and $\mathrm{Cd}$ contributed to this extreme 
532 situation in Bhaluka as well total Mymensingh district where industrial effluents or 533 anthropogenic origins act as the primary source (Al Zabir et al., 2016; Hossain et al., 2015).

534 On the column of the dendrogram, distances between clusters helped to understand the 535 typical pattern between metals. Where figure 8 confirmed four clumps of the metals that 536 contributed to four individually similar patterns in sampling sites but highly distinct among 537 each other. The order of the clusters presented here based on the distance between clusters like $\mathrm{Pb}-\mathrm{Ni}(4.427$, cluster 1$)<\mathrm{Pb}-\mathrm{Cu}(5.323$, cluster 2$)<\mathrm{Pb}-\mathrm{Cr}(6.133$, cluster 3$)<\mathrm{Cd}-\mathrm{Pb}$ (7.470, cluster 4) (Fig. 8). Low distance between metals indicates their higher association or

540 similar pattern of the data. Similarly, high distance reflects a lower association between metals 541 or different patterns of the values. In this study, the $\mathrm{Cd}$ and $\mathrm{Pb}$ association of cluster 4 detects

542 alternative data levels, like in post-monsoon, higher Cd concentrations recorded from sampling locations but the lowest loads estimated for $\mathrm{Pb}$ content. pattern of data distribution and became useful to make decisions in the formation of groups among common sampling areas and to find out the origin of the metals (Simeonov et al., 2000).

\section{Conclusions}

Heavy metal contamination in food items like fish, made this topic the most concerning issue as for the extreme health hazards. Keeping the alarming situation in mind, the present study was designed on the cultured pangas of Mymensingh to highlight the distribution of the metals in fish and the pattern of their risk on an adult human after consumption.

552 Comprehensively shocking findings documented in this write up is that a significantly higher

553 deposition of $\mathrm{Cd}, \mathrm{Pb}, \mathrm{Ni}$, and $\mathrm{Cu}$ observed in pangas tissues in each tested site. Therefore, eating contaminated fish liver and muscle could be dangerous for human health. To seek out the source of metals accumulation, pangas and their feed samples tested in which significant variations were observed in each study area. However, seasonal variations interfered to change 
the pattern of metals distribution, which established in this study. Besides, in this investigation, elements with significant positive (between $\mathrm{Pb}-\mathrm{Ni}$ and $\mathrm{Pb}-\mathrm{Cu}$ ) and negative $(\mathrm{Cd}-\mathrm{Ni}$ ) associations were recorded among sampling sites. Daily higher intake of metals crosses the

560 recommended line that influenced the higher effects on non-carcinogenic health hazards. The

561 highly adverse hazard index indicated the chronic risk of intaking pangas of studied sites.

562 However, no carcinogenic risk was observed due to the lower CR value of lead. Thus, considering all the issues, the present study strongly recommended several strategies such as

564 the incorporation of good quality fish feed in the farm, controlling the discharge of the

565 industrial pollutants and other anthropogenic ingredients directly into the natural waterways

566 and by the proper purification of the source water for aquaculture would be helpful to resolve

567 this severe threat impose to human health, thereby sustaining the pangasius aquaculture in

568 Bangladesh. In this study, we could not collect enough fish samples during the post-monsoon period. In the future work plan, the sample size of fish, water and soil needs to be increased.

\section{Acknowledgements}

571 We thank Mst Khadiza Begum for her assistance in laboratory works and useful revision of the 572 manuscript.

\section{Declarations}

\section{$574 \quad$ Funding}

575 This research did not receive any specific grant from funding agencies in the public, 576 commercial, or not-for-profit sectors. However, Md Abdullah-hil Maruf received National 577 Science and Technology (NST) fellowship of Bangladesh as MS research student.

\section{Conflicts of interest/Competing interests}

580 relationships that could have appeared to influence the work reported in this article. 
$581 \quad$ Ethics approval

582 Not applicable

583 Consent to participate

$584 \quad$ Not applicable

585 Consent for publication

586 All of the authors have read and approved the paper for submission of publication.

587 Availability of data and materials

588 The data that support the findings of this study are available on request from the corresponding

589 author.

590 Code availability

$591 \quad$ Not applicable 
593

594

595

596

597

598

599

600

601

602

603

604

605

606

607

608

609

610

611

612

613

614

615

616

617

618

619

620

621

622

623

624

625

626

627

628

629

630

631

632

633

Ahmed, A.S.S., Sultana, S., Habib, A., Ullah, H., Musa, N., Hossain, M.B., Rahman, M.M., Sarker, M.S.I., 2019. Bioaccumulation of heavy metals in some commercially important fishes from a tropical river estuary suggests higher potential health risk in children than adults. PLoS One 14. https://doi.org/10.1371/journal.pone.0219336.

Ahmed, G., Miah, M.A., Anawar, H.M., Chowdhury, D.A., Ahmad, J.U., 2012. Influence of multi-industrial activities on trace metal contamination: An approach towards surface water body in the vicinity of Dhaka Export Processing Zone (DEPZ). Environ. Monit. Assess. 184, 4181-4190. https://doi.org/10.1007/s10661-011-2254-9.

Ahmed, M.K., Shaheen, N., Islam, M.S., Habibullah-al-Mamun, M., Islam, S., Mohiduzzaman, M., Bhattacharjee, L., 2015. Dietary intake of trace elements from highly consumed cultured fish (Labeo rohita, Pangasius pangasius and Oreochromis mossambicus) and human health risk implications in Bangladesh. Chemosphere 128, 284-292. https://doi.org/10.1016/j.chemosphere.2015.02.016.

Ahmed, N., 2009. Revolution in small-scale freshwater rural aquaculture in Mymensingh, Bangladesh. World Aqua. 40, 31-35.

Akter, M., Zakir, H.M., Sharmin, S., Quadir, Q.F., Mehrin, S., 2020. Heavy metal bioaccumulation pattern in edible tissues of different farmed fishes of Mymensingh Area, Bangladesh and health risk assessment. Adv. Res. 21, 44-55. https://doi.org/10.9734/air/2020/v21i430200.

Al Zabir, A., Zaman, M.W.U., Hossen, M.Z., Uddin, M.N., Islam, M.S., Islam, M.S., 2016. Spatial dissemination of some heavy metals in soil adjacent to Bhaluka industrial area, Mymensingh, Bangladesh. Am. J. Appl. Sci. Res. 2, 38-47. https://doi.org/10.11648/j.ajasr.20160206.12.

Ali, H., Khan, E., 2017. What are heavy metals? Long-standing controversy over the scientific use of the term 'heavy metals'- proposal of a comprehensive definition. Toxicol. Environ. Chem. 100, 6-19. https://doi.org/10.1080/027722

Ali, H., Khan, E., 2018. Assessment of potentially toxic heavy metals and health risk in water, sediments, and different fish species of River Kabul, Pakistan. Hum. Ecol. Risk Assess. 24, 2101-2118. https://doi.org/10.1080/10807039.2018.1438175

Ali, M.H.H., Amaal, M.A., 2005. Studies of some heavy metals in water, sediment, fish and fish diets in some fish farms in EL-Fayoum province, Egypt. Egypt. J. Aquat. Res. 31, 261273.

Ali, N.A.A.H., Abu-Abdoun, I.I., Janaan, A.S., Hassan, J.H., Al Jeaidi, M.A., 2019. Investigation of selected heavy metals concentration in animal feeds in United Arab Emirates. Chem. Sci. Int. J. 28, 1-6. DOI: 10.9734/CSJI/2019/v28i330139.

Alizada, N., Malik, S., Muzaffar, S. Bin, 2020. Bioaccumulation of heavy metals in tissues of Indian anchovy (Stolephorus indicus) from the UAE coast, Arabian Gulf. Mar. Pollut. Bull. 154, p.111033. https://doi.org/10.1016/j.marpolbul.2020.111033.

Anhwange, B.A., Asemave, K., Kim, B.C., Nyiaatagher, D.T., 2012. Heavy metals contents of some synthetic fish feeds found within Makurdi metropolis. Int. J. Food Saf. Nutr. Publ. Health. 2, 55-61. 
Ashaiekh, M.A., Eltayeb, M.A.H., Ali, A.H., Ebrahim, A.M., Salih, I., Idris, A.M., 2019. Spatial distribution of total and bioavailable heavy metal contents in soil from agricultural, residential, and industrial areas in Sudan. Toxin Rev. 38, 93-105. https://doi.org/10.1080/15569543.2017.1419491.

Baeyens W., Parmentier K., Goeyens L., Ducastel G., De Gieter M., Leermakers M., 1998. The biogeochemical behaviour of $\mathrm{Cd}, \mathrm{Cu}, \mathrm{Pb}$ and $\mathrm{Zn}$ in the Scheldt estuary: results of the 1995 surveys, in: Baeyens W.F.J. (Eds.), Trace Metals in the Westerschelde Estuary: A CaseStudy of a Polluted, Partially Anoxic Estuary. Hydrobiologia, 366, Springer, Dordrecht, pp. 45-62. https://doi.org/10.1007/978-94-017-3573-5_3.45-62.

Baki, M.A., Hossain, M.M., Akter, J., Quraishi, S.B., Haque Shojib, M.F., Atique Ullah, A.K.M., Khan, M.F., 2018. Concentration of heavy metals in seafood (fishes, shrimp, lobster and crabs) and human health assessment in Saint Martin Island, Bangladesh. Ecotoxicol. Environ. Saf. 159, 153-163. https://doi.org/10.1016/j.ecoenv.2018.04.035.

Barakat, M.A., 2011. New Trends in Removing Heavy Metals from Industrial Wastewater. Arab. J. Chem. 4, 361-377. https://doi.org/10.1016/j.arabjc.2010.07.019.

BBS, 2015. Government of the People's Republic of Bangladesh. Bangladesh Bureau of Statistics, Ministry of Planning, Dhaka.

Burridge, L.E., Haya, K., Zitko, V., Waddy, S., 1999. The lethality of Salmosan (Azamethiphos) to American lobster (Homarus americanus) larvae, postlarvae, and adults. Ecotoxicol. Environ. Saf. 43, 165-169. https://doi.org/10.1006/eesa.1999.1771.

CEPA, 2009. Technical Support Document for Cancer potency Factors: Methodologies for derivation, listing of available values and adjustments to allow for early life stage exposures. https://oehha.ca.gov/media/downloads/crnr/tsdcancerpotency.pdf.

Dadar, M., Adel, M., Nasrollahzadeh Saravi, H., Fakhri, Y., 2017. Trace element concentration and its risk assessment in common kilka (Clupeonella cultriventris caspia Bordin, 1904) from southern basin of Caspian Sea. Toxin Rev. 36, 222-227. https://doi.org/10.1080/15569543.2016.1274762.

Duarte, G.S.C., Takemoto, R.M., Yamaguchi, M.U., de Matos, L.S., Pavanelli, G.C., 2019. Evaluation of the concentration of heavy metals in fillets of Pangasius hypophthalmus (Sauvage, 1878), Panga, imported from Vietnam. Int. J. Dev. Res. 9, 30181-30186.

Duffus, J.H., 2002. "heavy metals" - A meaningless term? (IUPAC technical report). Pure Appl. Chem. 74, 793-807. https://doi.org/10.1351/pac200274050793.

Duman, F., Aksoy, A., Demirezen, D., 2007. Seasonal variability of heavy metals in surface sediment of Lake Sapanca, Turkey. Environ. Monit. Assess. 133, 277-283. https://doi.org/10.1007/s10661-006-9580-3.

EC, 2003. Opinion of the scientific committee on animal nutrition on undesirable substances in feed.

Elnimr, T., 2011. Evaluation of some heavy metals in Pangasius hypothalmus and Tilapia nilotica and the role of acetic acid in lowering their levels. Int. J. Fish. Aquac. 3, 151-157.

EMEP, 2015. Heavy metals: Analysis of long-term trends, country-specific research and progress in mercury regional and global modelling. EMEP Status Rep. 2, 1-72.

Fallah, A.A., Saei-Dehkordi, S.S., Nematollahi, A., Jafari, T., 2011. Comparative study of 
heavy metal and trace element accumulation in edible tissues of farmed and wild rainbow trout (Oncorhynchus mykiss) using ICP-OES technique. Microchem. J. 98, 275-279. https://doi.org/10.1016/j.microc.2011.02.007.

FAO, 2000. Forest resources of Bangladesh - country report. Forest Resources Assessment Program, Forestry Department. FAO Working Paper 15, Rome.

FAO/WHO, 1984. List of maximum levels recommended for contaminants by the Joint FAO/WHO. Codex Alimentarius Commission.

FAO/WHO, 1989. Evaluation of certain food additives and the contaminants mercury, lead and cadmium. WHO Technical Report, Series No. 505.

Fergusson, J.E., 1990. The Heavy Elements: Chemistry, Environmental Impact and Health Effects, Pergamon Press, Oxford.

García-Lestón, J., Méndez, J., Pásaro, E., Laffon, B., 2010. Genotoxic effects of lead: An updated review. Environ. Int. 36, 623-636. https://doi.org/10.1016/j.envint.2010.04.011.

Gray, M.A., Harrins, A., Centeno, J.A., 2005. The role of cadmium, zinc, and selenium in prostate disease, in: Moore, T.A., Black, A., Centeno, J.A., Harding, J.S., Trumm, D.A. (Eds.), Metal contaminants in New Zealand: sources, treatments, and effects on ecology and human health. Christchurch: Resolutionz Press, pp. 393-414.

Gu, Y.G., Ouyang, J., An, H., Jiang, S.J., Tang, H.Q., 2017. Risk assessment and seasonal variation of heavy metals in settling particulate matter (SPM) from a typical southern Chinese mariculture base. Mar. Pollut. Bull. 123, 404-409. https://doi.org/10.1016/j.marpolbul.2017.08.044.

Henry, F., Amara, R., Courcot, L., Lacouture, D., Bertho, M.L., 2004. Heavy metals in four fish species from the French coast of the Eastern English Channel and Southern Bight of the North Sea. Environ. Int. 30, 675-683. https://doi.org/10.1016/j.envint.2003.12.007.

Hodson, P. V., 1988. The effect of metal metabolism on uptake, disposition and toxicity in fish. Aquat. Toxicol. 11, 3-18. https://doi.org/10.1016/0166-445X(88)90003-3.

Hossain, A., Saha, B., Rahman, M.M., Moniruzzaman, M., Begum, M., 2016. Heavy metal concentration and its toxicity assessment in some market fishes of Dhaka city. Int. J. Fish. Aquat. Stud. 4, 523-527.

Hossain, M.B., Ahmed, A.S.S., Sarker, M.S.I., 2018. Human health risks of Hg, As, Mn, and $\mathrm{Cr}$ through consumption of fish, Ticto barb (Puntius ticto) from a tropical river, Bangladesh. Environ. Sci. Pollut. Res. 25, 31727-31736. https://doi.org/10.1007/s11356018-3158-9.

Hossain, M.S., Zakir, H.M., Rahman, M.S., Islam, M.M., 2015. Toxic metallic contamination in wastewater of some industrial areas of Mymensingh town, Bangladesh. Advances in Architecture, City and Environment 1,7-13.

Huq, S.M.I., Alam, M.D., 2005. A handbook on analysis of soil, plant and water. BangladeshAustralia Centre for Environmental Research (BACER-DU), University of Dhaka, Bangladesh. pp. 1-246.

Ikem, A., Egiebor, N.O., 2005. Assessment of trace elements in canned fishes (mackerel , tuna, salmon, sardines and herrings) marketed in Georgia and Alabama (United States of America). J. Food Compost. Anal. 18, 771-787. https://doi.org/10.1016/j.jfca.2004.11.002. 
Islam, G.M.R, Habib, M.R., Waid, J.L., Rahman, M.S., Kabir, J., Akter, S., Jolly, Y.N., 2017. Heavy metal contamination of freshwater prawn (Macrobrachium rosenbergii) and prawn feed in Bangladesh: A market-based study to highlight probable health risks. Chemosphere 170, 282-289. https://doi.org/10.1016/j.chemosphere.2016.11.163.

Islam, M.S., Hossain, M.B., Matin, A., Islam Sarker, M.S., 2018. Assessment of heavy metal pollution, distribution and source apportionment in the sediment from Feni River estuary, Bangladesh. Chemosphere 202, 25-32. https://doi.org/10.1016/j.chemosphere.2018.03.077.

Islam, S., Ahmed, K., Habibullah-Al-Mamun, M., Masunaga, S., 2015. Potential ecological risk of hazardous elements in different land-use urban soils of Bangladesh. Sci. Total Environ. 512-513, 94-102. https://doi.org/10.1016/j.scitotenv.2014.12.100.

JECFA, 2019. Joint FAO/WHO Expert Committee on Food Additives. Food Contaminants. http://apps.who.int/foodadditives-contaminants-jecfa-database/search.aspx (accessed 24 May 2020).

Kamruzzaman, Mahamud, M.A., Alim, A., Hossen, M.S., Islam, M.A., Mansur, M.A., 2018. Study on heavy metal content of Oreochromis niloticus, Heteropneustes fossilis and Pangasius sutchi collected from pond and open water. Res. Agric. Livest. Fish. 5, 117126. https://doi.org/10.3329/ralf.v5i1.36560.

Kim, S.G., Kang, J.C., 2004. Effect of dietary copper exposure on accumulation, growth and hematological parameters of the juvenile rockfish, Sebastes schlegeli. Mar. Environ. Res. 58, 65-82. https://doi.org/10.1016/j.marenvres.2003.12.004.

Le, H.T., Ngo, H.T.T., 2013. Cd, Pb, and $\mathrm{Cu}$ in water and sediments and their bioaccumulation in freshwater fish of some lakes in Hanoi, Vietnam. Toxicol. Environ. Chem. 95, 13281337. https://doi.org/10.1080/02772248.2013.877462.

Lei, M., Tie, B.Q., Song, Z.G., Liao, B.H., Lepo, J.E., Huang, Y.Z., 2015. Heavy metal pollution and potential health risk assessment of white rice around mine areas in Hunan Province, China. Food Secur. 7, 45-54. https://doi.org/10.1007/s12571-014-0414-9.

Li, L., Xu, Z., Wu, J., Tian, G., 2010. Bioresource technology bioaccumulation of heavy metals in the earthworm Eisenia fetida in relation to bioavailable metal concentrations in pig manure. Bioresour. Technol. 3430-3436. https://doi.org/10.1016/j.biortech.2009.12.085.

Loutfy, N., Fuerhacker, M., Tundo, P., Raccanelli, S., El Dien, A.G., Ahmed, M.T., 2006. Dietary intake of dioxins and dioxin-like PCBs, due to the consumption of dairy products, fish/seafood and meat from Ismailia city, Egypt. Sci. Total Environ. 370, 1-8. https://doi.org/10.1016/j.scitotenv.2006.05.012.

Mahdi Abkener, A., Yahyavi, M., Bahri, A., Jafaryan, H., 2018. Assessment of heavy metals pollution in muscle of sole (Cynoglossus arel), spiny lobster (Panulirus homarus) and sediments in the northern coasts of the Oman Sea during pre and post monsoon. Iran. J. Fish. Sci. 0. https://doi.org/10.22092/ijfs.2018.124017.1006.

Mansour, S.A., Belal, M.H., Abou-Arab, A.A.K., Gad, M.F., 2009. Monitoring of pesticides and heavy metals in cucumber fruits produced from different farming systems. Chemosphere 75, 601-609. https://doi.org/10.1016/j.chemosphere.2009.01.058.

Milenkovic, B., Stajic, J.M., Stojic, N., Pucarevic, M., Strbac, S., 2019. Evaluation of heavy 
metals and radionuclides in fish and seafood products. Chemosphere 229, 324-331. https://doi.org/10.1016/j.chemosphere.2019.04.189.

763

764

765

766

Mo, W.Y., Man, Y.B., Zhang, F., Wong, M.H., 2019. Fermented food waste for culturing Jade perch and Nile tilapia: Growth performance and health risk assessment based on metal/loids. J. Environ. Manage. 236, 236-244. https://doi.org/10.1016/j.jenvman.2019.01.102.

MOFL, 2014. Bangladesh Gazette, Bangladesh Ministry of Fisheries and Livestock, SRO no. 233/Ayen.

Mwakalapa, E.B., Simukoko, C.K., Mmochi, A.J., Mdegela, R.H., Berg, V., Bjorge Müller, M.H., Lyche, J.L., Polder, A., 2019. Heavy metals in farmed and wild milkfish (Chanos chanos) and wild mullet (Mugil cephalus) along the coasts of Tanzania and associated health risk for humans and fish. Chemosphere 224, 176-186. https://doi.org/10.1016/j.chemosphere.2019.02.063.

Nguyen, B.T., Do, D.D., Nguyen, T.X., Nguyen, V.N., Phuc Nguyen, D.T., Nguyen, M.H., Thi Truong, H.T., Dong, H.P., Le, A.H., Bach, Q.V., 2020. Seasonal, spatial variation, and pollution sources of heavy metals in the sediment of the Saigon River, Vietnam. Environ. Pollut. 256, 113412. https://doi.org/10.1016/j.envpol.2019.113412.

Nofal, M.I., Zaki, V.H., Ahmed, N.A.S., 2019. Effects of heavy metal pollution on Nile tilapia in Manzala farm : Oxidative stress biomarkers and histopathological findings. Int. J. Fish. Aquat. Stud. 7, 315-328.

Økland, H.M.W., Stoknes, I.S., Remme, J.F., Kjerstad, M., Synnes, M., 2005. Proximate composition, fatty acid and lipid class composition of the muscle from deep-sea teleosts and elasmobranchs. Comp. Biochem. Physiol. - B Biochem. Mol. Biol. 140, 437-443. https://doi.org/10.1016/j.cbpc.2004.11.008.

Orban, E., Nevigato, T., Di Lena, G., Masci, M., Casini, I., Gambelli, L., Caproni, R., 2008. New trends in the seafood market. Sutchi catfish (Pangasius hypophthalmus) fillets from Vietnam: Nutritional quality and safety aspects. Food Chem. 110, 383-389. https://doi.org/10.1016/j.foodchem.2008.02.014.

Pal, D., Maiti, S.K., 2018. Seasonal variation of heavy metals in water, sediment, and highly consumed cultured fish (Labeo rohita and Labeo bata) and potential health risk assessment in aquaculture pond of the coal city, Dhanbad (India). Environ. Sci. Pollut. Res. 25, 1246412480. https://doi.org/10.1007/s11356-018-1424-5.

Rajeshkumar, S., Li, X., 2018. Bioaccumulation of heavy metals in fish species from the Meiliang Bay, Taihu Lake, China. Toxicol. Reports 5, 288-295. https://doi.org/10.1016/j.toxrep.2018.01.007.

Rani Das, P., Hossain, M.K., Sarker, B.S., Parvin, A., Swarna Das, S., Moniruzzaman, M., Saha, B., 2017. Heavy metals in farm sediments, feeds and bioaccumulation of some selected heavy metals in various tissues of farmed Pangasius hypophthalmus in Bangladesh. Fish. Aquac. J. 08. https://doi.org/10.4172/2150-3508.1000218.

Sabbir, W., Rahman, M.Z., Khan, M.N., Sabbir, C.W., Halder, T., Ray, S., 2018. Assessment of heavy metal contamination in fish feed available in three districts of South Western region of Bangladesh. Int. J. Fish. Aquat. Stud. 6, 100-104.

Saha, B., Mottalib, M.A., Al Razee, A.N.M., 2018. Assessment of selected heavy metals 
808

809

810

811

812

813

814

815

816

817

818

819

820

821

822

823

824

825

826

827

828

829

830

831

832

833

834

835

836

837

838

839

840

841

842

843

844

845 concentration in different brands of fish feed available in Bangladesh. J. Bangladesh Acad. Sci. 42, 207-210.

Saha, N., Mollah, M.Z.I., Alam, M.F., Rahman, M.S., 2016. Seasonal investigation of heavy metals in marine fishes captured from the Bay of Bengal and the implications for human health risk assessment. Food Control 70, 110-118. https://doi.org/10.1016/j.foodcont.2016.05.040.

Shaheen, N., Ahmed, M.K., Islam, M.S., Habibullah-Al-Mamun, M., Tukun, A.B., Islam, S., Abu, A.T., 2016. Health risk assessment of trace elements via dietary intake of 'non-piscine protein source' foodstuffs (meat, milk and egg) in Bangladesh. Environ. Sci. Pollut. Res. 23, 7794-7806. https://doi.org/10.1007/s11356-015-6013-2.

Shamshad, B.Q., Shahidur, R.K., Tasrena, R.C., 2009. Studies on toxic elements accumulation in shrimp from fish feed used in Bangladesh. As. J. Food Ag-Ind. 2, 440-444.

Siddiqy, M.R., 2017. Urban environment and major challenges in sustainable development: Experience from Dhaka City in Bangladesh. South East Asia J. Public Heal. 7, 12-16. https://doi.org/10.3329/seajph.v7i1.34673.

Simeonov, V., Massart, D.L., Andreev, G., Tsakovski, S., 2000. Assessment of metal pollution based on multivariate statistical modeling of "hot spot" sediments from the Black Sea. Chemosphere 41, 1411-1417. https://doi.org/10.1016/S0045-6535(99)00540-8.

Sow, A.Y., Ismail, A., Zulkifli, S.Z., Amal, M.N., Hambali, K., 2019. Seasonal variation of heavy metals and metallothionein contents in Asian swamp eels, Monopterus albus (Zuiew, 1793) from Tumpat, Kelantan, Malaysia. BMC Pharmacol. Toxicol. 20, 1-8. https://doi.org/10.1186/s40360-019-0286-X.

Stone, N.J., 1996. Fish consumption, fish oil, lipids, and coronary heart disease. Circulation 94, 2337-2340.

Strungaru, S.A., Nicoara, M., Gorban, C.F., Paduraru, E., Plavan, G.I., 2020. Toxic metal contamination and total organic carbon content in the meat of the main fish species imported and sold in Romanian's supermarkets 6, 45-54.

Sunjog, K., Kolarević, S., Kračun-Kolarević, M., Višnjić-Jeftić, Ž., Gačić, Z., Lenhardt, M., Vuković-Gačić, B., 2019. Seasonal variation in metal concentration in various tissues of the European chub (Squalius cephalus L.). Environ. Sci. Pollut. Res. 26, 9232-9243. https://doi.org/10.1007/s11356-019-04274-3.

Tchounwou, P.B., Yedjou, C.G., Patlolla, A.K., Sutton, D.J., 2012. Molecular, clinical and environmental toxicicology v3: Environmental Toxicology. Mol. Clin. Environ. Toxicol. 101, 133-164. https://doi.org/10.1007/978-3-7643-8340-4.

Türkmen, A., Türkmen, M., Tepe, Y., Akyurt, I., 2005. Heavy metals in three commercially valuable fish species from Iskenderun Bay, Northern East Mediterranean Sea, Turkey. Food Chem. 91, 167-172. doi:10.1016/j.foodchem.2004.08.008.

USEPA, 1989. Risk assessment guidance for superfund. Human Health Evaluation Manual. EPA/540/1-89/002. Office of Emergency and Remedial Response, v1. Washington, DC.

USEPA, 2010. Integrated Risk Information System (IRIS); United States Environmental Protection Agency: Washington, DC, USA. http://www.epa.gov/ncea/iris/index.html (accessed 1 May 2020). 
USEPA, 2011. USEPA regional screening level (RSL) summary table: November 2011. https://www.epa.gov/risk/regional-screening-levels-rsls-generic-tables (accessed 27 April 2020).

USEPA, 2020. Regional Screening Levels (RSL). Superfund Risk Assessment. https://epaprgs.ornl.gov/cgi-bin/chemicals/csl_search/ (accessed 19 April 2020).

USFDA, 1993. Food and drug administration Guidance document for arsenic in shellfish. DHHS/PHS/FDA/CFSAN/Office of Seafood. Washington DC.

Vannoort, R.W., Thomson, B.M., 2005. 2003/04 New Zealand total diet survey - Agricultural compound residues, selected contaminants and nutrients. https://www.mpi.govt.nz/dmsdocument/4004/direct (accessed 20 August 2020).

Walker, C.H., Sibly, R.M., Hopkin, S.P., Peakall, D.B., 2012. Principles of Ecotoxicology. 4th edn. Boca Raton: CRC Press.

Wang, W., Wang, W.X., 2016. Phase partitioning of trace metals in a contaminated estuary influenced by industrial effluent discharge. Environ. Pollut. 214, 35-44. https://doi.org/10.1016/j.envpol.2016.03.059.

WHO, 1985. Guidelines for Drinking Water Quality. Recommendation WHO 1, Geneva, pp. 130.

WHO, 2011. WHO Guidelines for Drinking Water Quality, fourth ed. WHO Publications, Geneva, Switzerland, pp. 307-340, ISBN 9789241548151.

Zhang, H., Cui, B., Xiao, R., Zhao, H., 2010. Heavy metals in water, soils and plants in riparian wetlands in the Pearl River Estuary, South China. Procedia Environ. Sci. 2, 1344-1354. https://doi.org/10.1016/j.proenv.2010.10.145. 


\section{Table 1}

870 Operating parameters and recovery percentages of Atomic absorption spectrometer (AAS) for 871 working elements

872

\begin{tabular}{lllll}
\hline $\begin{array}{l}\text { Heavy } \\
\text { metals }\end{array}$ & $\begin{array}{l}\text { Wave length } \\
(\mathrm{nm})\end{array}$ & $\begin{array}{l}\text { Lamp intensity } \\
(\mathrm{mA})\end{array}$ & $\begin{array}{l}\text { Slit intensity } \\
(\mathrm{nm})\end{array}$ & $\begin{array}{l}\text { Recovery percentage } \\
(\%)\end{array}$ \\
\hline $\mathrm{Cd}$ & 228.8 & 4 & 0.5 & 98 \\
$\mathrm{~Pb}$ & 217.3 & 10 & 1 & 109 \\
$\mathrm{Ni}$ & 232 & 4 & 0.2 & 97 \\
$\mathrm{Cu}$ & 324.8 & 4 & 0.5 & 106 \\
$\mathrm{Cr}$ & 357.9 & 7 & 0.2 & 101 \\
\hline
\end{tabular}




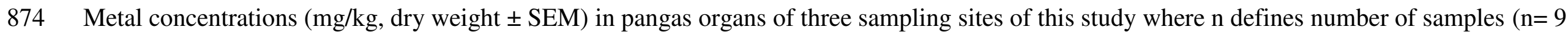

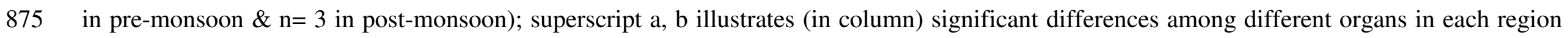

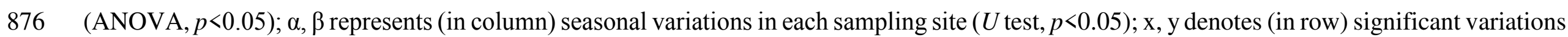

877 among sampling sites in each sampling season (ANOVA, $p<0.05$ ).

\begin{tabular}{|c|c|c|c|c|c|c|c|}
\hline Sampling site & Organ of pangas & Sampling season & $\mathrm{Cd}$ & $\mathrm{Pb}$ & $\mathrm{Ni}$ & $\mathrm{Cu}$ & $\mathrm{Cr}$ \\
\hline \multirow[t]{8}{*}{ Muktagacha } & \multirow[t]{2}{*}{ Gill } & Pre-monsoon & $0.03 \pm 0.02^{\mathrm{a}}$ & $0.11 \pm 0.06^{\mathrm{a}}$ & $23.35 \pm 3.26^{\mathrm{a}}$ & $1.33 \pm 0.14^{\mathrm{a}}$ & $0.00 \pm 0.00^{\mathrm{a}}$ \\
\hline & & Post-monsoon & $0.73 \pm 0.00^{\mathrm{a}}$ & $0.00 \pm 0.00^{\mathrm{a}}$ & $3.79 \pm 0.00^{\mathrm{a}}$ & $0.73 \pm 0.00^{\mathrm{a}}$ & $0.00 \pm 0.00^{\mathrm{a}}$ \\
\hline & \multirow[t]{2}{*}{ Liver } & 2, & $0.09 \pm 0.05^{\mathrm{a}}$ & $2.15 \pm 0.18^{\mathrm{b}}$ & $62.37 \pm 17.45^{\mathrm{a}}$ & $35.47 \pm 9.51^{\mathrm{b}}$ & $0.00 \pm 0.00^{\mathrm{a}}$ \\
\hline & & 2 & $0.62 \pm 0.00^{\mathrm{a}}$ & $0.00 \pm 0.00^{\mathrm{a}}$ & $0.00 \pm 0.00^{\mathrm{a}}$ & $0.62 \pm 0.00^{\mathrm{a}}$ & $0.00 \pm 0.00^{\mathrm{a}}$ \\
\hline & \multirow[t]{2}{*}{ Muscle } & , & $0.05 \pm 0.01^{\mathrm{a}}$ & $0.24 \pm 0.24^{\mathrm{a}}$ & $60.5 \pm 31.94^{\mathrm{a}}$ & $1.03 \pm 0.24^{\mathrm{a}}$ & $0.09 \pm 0.09^{\mathrm{a}}$ \\
\hline & & , & $0.73 \pm 0.00^{\mathrm{a}}$ & $0.00 \pm 0.00^{\mathrm{a}}$ & $0.00 \pm 0.00^{\mathrm{a}}$ & $0.73 \pm 0.00^{\mathrm{a}}$ & $0.00 \pm 0.00^{\mathrm{a}}$ \\
\hline & \multirow{2}{*}{$\begin{array}{l}\text { Total } \\
\text { contain }\end{array}$} & , & $0.06 \pm 0.02^{\alpha x}$ & $0.83 \pm 0.34^{\alpha x}$ & $48.74 \pm 12.32^{\alpha x}$ & $12.61 \pm 6.34^{\alpha x}$ & $0.03 \pm 0.03^{\alpha x}$ \\
\hline & & , & $0.69 \pm 0.04^{\beta x}$ & $0.00 \pm 0.00^{\beta \mathrm{x}}$ & $1.26 \pm 1.26^{\alpha x}$ & $0.69 \pm 0.04^{\beta x}$ & $0.00 \pm 0.00^{\alpha x}$ \\
\hline \multirow[t]{8}{*}{ Trishal } & \multirow[t]{2}{*}{ Gill } & , & $0.03 \pm 0.02^{\mathrm{a}}$ & $0.65 \pm 0.57^{\mathrm{a}}$ & $36.60 \pm 13.75^{\mathrm{a}}$ & $1.50 \pm 0.19^{a}$ & $0.09 \pm 0.09^{\mathrm{a}}$ \\
\hline & & , & $0.51 \pm 0.00^{\mathrm{a}}$ & $0.00 \pm 0.00^{\mathrm{a}}$ & $6.32 \pm 0.00^{\mathrm{a}}$ & $0.51 \pm 0.00^{\mathrm{a}}$ & $0.00 \pm 0.00^{\mathrm{a}}$ \\
\hline & \multirow[t]{2}{*}{ Liver } & , & $0.05 \pm 0.01^{\mathrm{a}}$ & $0.00 \pm 0.00^{\mathrm{a}}$ & $47.70 \pm 12.51^{\mathrm{a}}$ & $43.30 \pm 8.76^{\mathrm{b}}$ & $0.16 \pm 0.08^{a}$ \\
\hline & & , & $0.73 \pm 0.00^{\mathrm{a}}$ & $0.00 \pm 0.00^{\mathrm{a}}$ & $0.00 \pm 0.00^{\mathrm{a}}$ & $0.73 \pm 0.00^{\mathrm{a}}$ & $0.00 \pm 0.00^{\mathrm{a}}$ \\
\hline & \multirow[t]{2}{*}{ Muscle } & , & $0.03 \pm 0.02^{\mathrm{a}}$ & $1.19 \pm 0.67^{\mathrm{a}}$ & $102.78 \pm 37.12^{\mathrm{a}}$ & $0.60 \pm 0.31^{\mathrm{a}}$ & $0.00 \pm 0.00^{\mathrm{a}}$ \\
\hline & & , & $0.79 \pm 0.00^{\mathrm{a}}$ & $0.00 \pm 0.00^{\mathrm{a}}$ & $0.00 \pm 0.00^{\mathrm{a}}$ & $0.79 \pm 0.00^{\mathrm{a}}$ & $0.00 \pm 0.00^{\mathrm{a}}$ \\
\hline & \multirow{2}{*}{$\begin{array}{l}\text { Total } \\
\text { contain }\end{array}$} & , & $0.04 \pm 0.01^{\alpha x}$ & $0.61 \pm 0.31^{\alpha x}$ & $62.36 \pm 15.76^{\alpha y}$ & $15.13 \pm 7.48^{\alpha \mathrm{x}}$ & $0.08 \pm 0.04^{\alpha x}$ \\
\hline & & , & $0.68 \pm 0.09^{\beta x}$ & $0.00 \pm 0.00^{\alpha x}$ & $2.11 \pm 2.11^{\beta \mathrm{x}}$ & $0.68 \pm 0.09^{\alpha x}$ & $0.00 \pm 0.00^{\alpha x}$ \\
\hline \multirow[t]{8}{*}{ Bhaluka } & \multirow[t]{2}{*}{ Gill } & , & $0.05 \pm 0.01^{\mathrm{a}}$ & $0.24 \pm 0.24^{\mathrm{a}}$ & $39.91 \pm 18.69^{\mathrm{a}}$ & $1.62 \pm 0.20^{\mathrm{a}}$ & $0.03 \pm 0.03^{\mathrm{a}}$ \\
\hline & & , & $0.62 \pm 0.00^{\mathrm{a}}$ & $0.00 \pm 0.00^{\mathrm{a}}$ & $0.00 \pm 0.00^{\mathrm{a}}$ & $0.62 \pm 0.00^{\mathrm{a}}$ & $0.00 \pm 0.00^{\mathrm{a}}$ \\
\hline & \multirow[t]{2}{*}{ Liver } & , & $0.06 \pm 0.01^{\mathrm{a}}$ & $1.92 \pm 1.58^{\mathrm{a}}$ & $37.70 \pm 14.21^{\mathrm{a}}$ & $45.94 \pm 4.58^{\mathrm{b}}$ & $0.00 \pm 0.00^{\mathrm{a}}$ \\
\hline & & & $0.45 \pm 0.00^{\mathrm{a}}$ & $0.00 \pm 0.00^{\mathrm{a}}$ & $1.27 \pm 0.00^{\mathrm{a}}$ & $0.45 \pm 0.00^{\mathrm{a}}$ & $0.00 \pm 0.00^{\mathrm{a}}$ \\
\hline & \multirow[t]{2}{*}{ Muscle } & , & $0.04 \pm 0.04^{\mathrm{a}}$ & $0.00 \pm 0.00^{\mathrm{a}}$ & $22.44 \pm 3.45^{\mathrm{a}}$ & $0.74 \pm 0.23^{\mathrm{a}}$ & $0.00 \pm 0.00^{\mathrm{a}}$ \\
\hline & & & $0.68 \pm 0.00^{\mathrm{a}}$ & $0.00 \pm 0.00^{\mathrm{a}}$ & $8.22 \pm 0.00^{\mathrm{a}}$ & $0.68 \pm 0.00^{\mathrm{a}}$ & $0.00 \pm 0.00^{\mathrm{a}}$ \\
\hline & \multirow{3}{*}{$\begin{array}{l}\text { Total } \\
\text { contain } \\
\text { For fish }\end{array}$} & , & $0.05 \pm 0.01^{\alpha x}$ & $0.72 \pm 0.23^{\alpha x}$ & $48.15 \pm 7.21^{\alpha x}$ & $14.61 \pm 3.98^{\alpha x}$ & $0.04 \pm 0.02^{\alpha x}$ \\
\hline & & , & $0.58 \pm 0.07^{\beta x}$ & $0.00 \pm 0.00^{\alpha x}$ & $3.16 \pm 2.55^{\beta \mathrm{x}}$ & $0.58 \pm 0.07^{\alpha x}$ & $0.00 \pm 0.00^{\alpha x}$ \\
\hline Standard permissible limit & & & $0.5^{\S}$ & $0.5^{\S}$ & $80^{\ddagger}$ & $30^{\S}$ & $0.05^{\dagger}$ \\
\hline
\end{tabular}

$878 \quad{ }^{\S} \mathrm{FAO} / \mathrm{WHO}(1989),{ }^{\ddagger} \mathrm{USFDA}(1993),{ }^{\dagger} \mathrm{WHO}(2011)$ 
880 Pearson correlation analysis of metal contents in pangas within each sampling area during pre-monsoon (stars indicates 2-tailed significance value 881 at $1 \%$ level of significance).

\begin{tabular}{|c|c|c|c|c|c|c|c|c|c|c|c|c|c|c|c|}
\hline \multirow{3}{*}{$\begin{array}{l}\text { Heavy } \\
\text { metals }\end{array}$} & \multicolumn{15}{|c|}{ Pearson correlations $(r)$} \\
\hline & \multicolumn{5}{|c|}{ Muktagacha } & \multicolumn{5}{|c|}{ Trishal } & \multicolumn{5}{|c|}{ Bhaluka } \\
\hline & $\mathrm{Cd}$ & $\mathrm{Pd}$ & $\mathrm{Ni}$ & $\mathrm{Cu}$ & $\mathrm{Cr}$ & $\mathrm{Cd}$ & $\mathrm{Pd}$ & $\mathrm{Ni}$ & $\mathrm{Cu}$ & $\mathrm{Cr}$ & $\mathrm{Cd}$ & $\mathrm{Pd}$ & $\mathrm{Ni}$ & $\mathrm{Cu}$ & $\mathrm{Cr}$ \\
\hline \multicolumn{16}{|l|}{$\mathrm{Cd}$} \\
\hline $\mathrm{Pb}$ & 0.543 & & & & & 0.430 & & & & & 0.008 & & & & \\
\hline $\mathrm{Ni}$ & 0.461 & 0.331 & & & & 0.361 & 0.662 & & & & 0.234 & 0.311 & & & \\
\hline $\mathrm{Cu}$ & 0.330 & $0.900^{* *}$ & 0.253 & & & 0.448 & -0.474 & -0.302 & & & 0.252 & 0.430 & 0.153 & & \\
\hline $\mathrm{Cr}$ & 0.080 & -0.305 & -0.403 & -0.232 & & .605 & 0.043 & -0.250 & 0.461 & & 0.006 & -0.163 & 0.619 & -0.245 & \\
\hline
\end{tabular}

$882 * *$ Significant at $1 \%$ level $(P<0.01)$

\section{Table 3 B}

884 Pearson correlation analysis of metal contents in pangas within each sampling area during post-monsoon (stars indicates 2-tailed significance value 885 at $1 \%$ level of significance).

\begin{tabular}{|c|c|c|c|c|c|c|c|c|c|c|c|c|c|c|c|}
\hline \multirow{3}{*}{$\begin{array}{l}\text { Heavy } \\
\text { metals }\end{array}$} & \multicolumn{15}{|c|}{ Pearson correlation $(r)$} \\
\hline & \multicolumn{5}{|c|}{ Muktagacha } & \multicolumn{5}{|l|}{ Trishal } & \multicolumn{5}{|l|}{ Bhaluka } \\
\hline & $\mathrm{Cd}$ & $\mathrm{Pd}$ & $\mathrm{Ni}$ & $\mathrm{Cu}$ & $\mathrm{Cr}$ & $\mathrm{Cd}$ & $\mathrm{Pd}$ & $\mathrm{Ni}$ & $\mathrm{Cu}$ & $\mathrm{Cr}$ & $\mathrm{Cd}$ & $\mathrm{Pd}$ & $\mathrm{Ni}$ & $\mathrm{Cu}$ & $\mathrm{Cr}$ \\
\hline $\mathrm{Cd}$ & & & & & & & & & & & & & & & \\
\hline $\mathrm{Pb}$ & 0.0 & & & & & 0.0 & & & & & 0.0 & & & & \\
\hline $\mathrm{Ni}$ & 0.500 & 0.0 & & & & -0.980 & 0.0 & & & & 0.578 & 0.0 & & & \\
\hline $\mathrm{Cu}$ & $1.000^{* *}$ & 0.0 & 0.500 & & & $1.000^{* * *}$ & 0.0 & -0.980 & & & $1.000^{* *}$ & 0.0 & 0.578 & & \\
\hline $\mathrm{Cr}$ & 0.0 & 0.0 & 0.0 & 0.0 & & 0.0 & 0.0 & 0.0 & 0.0 & & 0.0 & 0.0 & 0.0 & 0.0 & \\
\hline
\end{tabular}

$* *$ Significant at $1 \%$ level $(P<0.01)$ 
887 Table $3 \mathrm{C}$

888 Pearson correlation analysis of metal contents in pangas of Mymensingh district during 2017 889 (stars indicates 2 -tailed significance value at $* 1$ and $5 \%$ level of significance).

\begin{tabular}{llllll}
\hline & $\mathrm{Cd}$ & $\mathrm{Pd}$ & $\mathrm{Ni}$ & $\mathrm{Cu}$ & $\mathrm{Cr}$ \\
\hline $\mathrm{Cd}$ & & & & & \\
$\mathrm{Pb}$ & -0.251 & & & & \\
$\mathrm{Ni}$ & $-0.486^{* *}$ & $0.440^{* *}$ & & & \\
$\mathrm{Cu}$ & -0.280 & $0.360^{*}$ & 0.146 & & \\
$\mathrm{Cr}$ & -0.192 & -0.035 & 0.025 & 0.175 & \\
\hline
\end{tabular}

890 $* 5 \%$ level of significance $(p<0.05) ; * *$ Significant at $1 \%$ level $(p<0.01)$ 
892 Multiple regression model results for testing the effect of changing different feed heavy metals concentrations on studied pangas metal 893 compositions that used for their feeding in farms of Mymensingh. Bold values represent their significance at 5\% level.

\begin{tabular}{|c|c|c|c|c|c|c|c|c|c|c|}
\hline \multirow{2}{*}{$\begin{array}{l}\text { Response } \\
\text { variable } \\
\text { Cd in Pangas }\end{array}$} & \multirow{2}{*}{$\begin{array}{l}\text { Intercept/ } \alpha \\
-0.089\end{array}$} & \multirow{2}{*}{$\begin{array}{l}\text { Predictors in } \\
\text { the model } \\
\text { Cd in Feed }\end{array}$} & \multicolumn{2}{|c|}{$\begin{array}{l}\text { Estimated } \\
\beta \text { value }\end{array}$} & SE & $\begin{array}{l}\mathrm{P} \text { value of } \\
t \text {-test }\end{array}$ & $\begin{array}{l}\mathrm{P} \text { value of } \\
\text { F-test }\end{array}$ & F ratio & $\mathrm{R}^{2}$ & $\begin{array}{l}\text { Adjusted } \\
\mathrm{R}^{2}\end{array}$ \\
\hline & & & $\beta_{1}$ & -0.011 & 0.041 & 0.807 & 0.4433 & 1.164 & 0.538 & 0.076 \\
\hline & & $\mathrm{Pb}$ in Feed & $\beta_{2}$ & 0.116 & 0.06 & 0.127 & & & & \\
\hline & & $\mathrm{Ni}$ in Feed & $\beta_{3}$ & $2.940 \mathrm{E}^{-6}$ & $3.174 \mathrm{E}^{-5}$ & 0.931 & & & & \\
\hline & & $\mathrm{Cu}$ in Feed & $\beta_{4}$ & 0.0241 & 0.019 & 0.282 & & & & \\
\hline & & $\mathrm{Cr}$ in Feed & $\beta_{5}$ & 0 & 0 & - & & & & \\
\hline \multirow{5}{*}{$\mathrm{Pb}$ in Pangas } & -0.287 & $\mathrm{Cd}$ in Feed & $\beta_{1}$ & -0.819 & 1.317 & 0.568 & 0.9425 & 0.171 & 0.146 & -0.709 \\
\hline & & $\mathrm{Pb}$ in Feed & $\beta_{2}$ & 0.630 & 1.930 & 0.761 & & & & \\
\hline & & $\mathrm{Ni}$ in Feed & $\beta_{3}$ & -0.001 & 0.001 & 0.634 & & & & \\
\hline & & $\mathrm{Cu}$ in Feed & $\beta_{4}$ & 0.299 & 0.621 & 0.655 & & & & \\
\hline & & $\mathrm{Cr}$ in Feed & $\beta_{5}$ & 0 & 0 & - & & & & \\
\hline \multirow[t]{5}{*}{$\mathrm{Ni}$ in Pangas } & 54.92 & Cd in Feed & $\beta_{1}$ & -42.676 & 27.1704 & 0.1914 & 0.5114 & 0.9699 & 0.492 & -0.015 \\
\hline & & $\mathrm{Pb}$ in Feed & $\beta_{2}$ & 0.122 & 39.833 & 0.998 & & & & \\
\hline & & $\mathrm{Ni}$ in Feed & $\beta_{3}$ & -0.0087 & 0.021 & 0.6985 & & & & \\
\hline & & $\mathrm{Cu}$ in Feed & $\beta_{4}$ & 3.820 & 12.814 & 0.7804 & & & & \\
\hline & & $\mathrm{Cr}$ in Feed & $\beta_{5}$ & 0 & 0 & - & & & & \\
\hline \multirow[t]{5}{*}{$\mathrm{Cu}$ in Pangas } & -14.783 & Cd in Feed & $\beta_{1}$ & 3.146 & 3.337 & 0.399 & 0.0244 & 9.7486 & 0.907 & 0.814 \\
\hline & & $\mathrm{Pb}$ in Feed & $\beta_{2}$ & -10.984 & 4.892 & 0.088 & & & & \\
\hline & & $\mathrm{Ni}$ in Feed & $\beta_{3}$ & 0.009 & 0.003 & 0.027 & & & & \\
\hline & & $\mathrm{Cu}$ in Feed & $\beta_{4}$ & 4.361 & 1.574 & 0.0503 & & & & \\
\hline & & Cr in Feed & $\beta_{5}$ & 0 & 0 & - & & & & \\
\hline \multirow[t]{5}{*}{$\mathrm{Cr}$ in Pangas } & 0.109 & $\mathrm{Cd}$ in Feed & $\beta_{1}$ & -0.227 & 0.102 & 0.091 & 0.3097 & 1.701 & 0.6298 & 0.2596 \\
\hline & & $\mathrm{Pb}$ in Feed & $\beta_{2}$ & -0.252 & 0.1495 & 0.167 & & & & \\
\hline & & $\mathrm{Ni}$ in Feed & $\beta_{3}$ & $-8.464 \mathrm{E}^{-5}$ & $7.879 \mathrm{E}^{-5}$ & 0.343 & & & & \\
\hline & & $\mathrm{Cu}$ in Feed & $\beta_{4}$ & 0.0205 & 0.048 & 0.692 & & & & \\
\hline & & Cr in Feed & $\beta_{5}$ & 0 & 0 & - & & & & \\
\hline
\end{tabular}




\section{Table 5}

896 Hazard index of studied heavy metals for average adult pangas consumer in Mymensingh 897 district.

\begin{tabular}{lll}
\hline Sampling sites & HI & Recommended HI (Lei et al. 2015) \\
\hline Muktagacha & 8.184 & HI $\leq 1$ obvious adverse impact \\
Trishal & 9.837 & HI $>1$ most probable adverse impact \\
Bhaluka & 6.375 & HI $>10$ high or chronic of acute impact
\end{tabular}

898

899 
$900 \quad$ Table 6

901 Rotated component matrix and total explained variance of metals of pangas in Mymensingh

902 district where extraction method was principal component analysis and rotation method was

903 varimax with Kaiser normalization. Rotation converged in 3 iterations.

\begin{tabular}{lllllllll}
\hline Variable & $\mathrm{Cd}$ & $\mathrm{Pb}$ & $\mathrm{Ni}$ & $\mathrm{Cu}$ & $\mathrm{Cr}$ & Eigenvalue & $\begin{array}{l}\text { Variance } \\
\%\end{array}$ & $\begin{array}{l}\text { Cumulative } \\
\%\end{array}$ \\
\hline $\begin{array}{l}\text { Factor } \\
\text { (PC1) }\end{array}$ & -0.635 & 0.787 & 0.805 & 0.457 & -0.109 & 2.0204 & 40.408 & 40.408 \\
$\begin{array}{l}\text { Factor 2 } \\
\text { (PC2) }\end{array}$ & -0.402 & -0.064 & 0.0 & 0.472 & 0.910 & 1.0884 & 21.768 & 62.176 \\
\hline
\end{tabular}

904 


\section{$905 \quad$ Table 7}

906 Metal concentrations $(\mathrm{mg} / \mathrm{kg}$ ) in different pangas organs estimated by several authors in their studies.

\begin{tabular}{|c|c|c|c|c|c|c|c|c|}
\hline \multirow[t]{2}{*}{ Pangas species } & \multirow[t]{2}{*}{ Sampling sites } & \multirow[t]{2}{*}{ Organ type } & \multicolumn{5}{|l|}{ Heavy metals } & \multirow[t]{2}{*}{ References } \\
\hline & & & $\mathrm{Cd}$ & $\mathrm{Pb}$ & $\mathrm{Ni}$ & $\mathrm{Cu}$ & $\mathrm{Cr}$ & \\
\hline $\begin{array}{l}P . \\
\text { hypophthalmus }\end{array}$ & $\begin{array}{l}\text { Mymensingh, } \\
\text { Bangladesh }\end{array}$ & $\begin{array}{l}\text { Gill } \\
\text { Liver } \\
\text { Muscle }\end{array}$ & $\begin{array}{l}0.182 \pm 0.078 \\
0.202 \pm 0.072 \\
0.213 \pm 0.091\end{array}$ & $\begin{array}{l}0.249 \pm 0.152 \\
1.017 \pm 0.457 \\
0.357 \pm 0.212\end{array}$ & $\begin{array}{l}25.805 \pm 6.622 \\
37.048 \pm 8.820 \\
47.114 \pm 15.59\end{array}$ & $\begin{array}{l}1.266 \pm 0.135 \\
31.326 \pm 6.206 \\
0.774 \pm 0.011\end{array}$ & $\begin{array}{l}0.032 \pm 0.024 \\
0.039 \pm 0.027 \\
0.023 \pm 0.023\end{array}$ & Present study \\
\hline $\begin{array}{l}P . \\
\text { hypothalamus }\end{array}$ & Kafer-El-Zayat, Egypt & Muscle & $0.12 \pm 0.011$ & $0.79 \pm 0.05$ & - & - & - & Elnimr, 2011 \\
\hline$P$. pangasius & Bangladesh & $\begin{array}{l}\text { Muscle } \\
\text { Head }\end{array}$ & $0.01 \pm 0.00$ & $0.017 \pm 0.002$ & $0.012 \pm 0.002$ & $0.658 \pm 0.007$ & $1.349 \pm 0.033$ & Ahmed et al., 2015 \\
\hline $\begin{array}{l}P . \\
\text { hypothalamus }\end{array}$ & Dhaka city, Bangladesh & $\begin{array}{l}\text { Muscle } \\
\text { Liver }\end{array}$ & $\begin{array}{l}0.641 \\
0.616\end{array}$ & $\begin{array}{l}- \\
-\end{array}$ & $\begin{array}{l}144.683 \\
231.500\end{array}$ & $\begin{array}{l}- \\
-\end{array}$ & $\begin{array}{l}6.35 \\
7.45\end{array}$ & Hossain et al., 2016 \\
\hline $\begin{array}{l}P . \\
\text { hypophthalmus }\end{array}$ & $\begin{array}{l}\text { Noakhali districts, } \\
\text { Bangladesh }\end{array}$ & $\begin{array}{l}\text { Gill } \\
\text { Muscle } \\
\text { Liver }\end{array}$ & 0.16 & 6.29 & 4.23 & 11.96 & 11.03 & Das et al., 2017 \\
\hline P. sutchi & $\begin{array}{l}\text { Mymensingh, } \\
\text { Bangladesh }\end{array}$ & Muscle & $0.22 \pm 0.02$ & ND & - & $0.21 \pm 0.02$ & - & Kamruzzaman et al., 2018 \\
\hline $\begin{array}{l}P . \\
\text { hypothalamus }\end{array}$ & $\begin{array}{l}\text { Imported from Vietnam } \\
\text { for } \\
\text { supermarket }\end{array}$ & Muscle & $<0.05$ & $0.05-0.166$ & $<0.05$ & - & $<0.05$ & Duarte et al., 2019 \\
\hline P. sanitwongsei & $\begin{array}{l}\text { Imported from Vietnam } \\
\text { for Serbian supermarket }\end{array}$ & Edible part & 0.01 & 0.83 & - & - & - & Milenkovic et al., 2019 \\
\hline $\begin{array}{l}P . \\
\text { hypophthalmus }\end{array}$ & $\begin{array}{l}\text { Imported from Vietnam } \\
\text { for } \quad \text { Romanian } \\
\text { supermarket }\end{array}$ & Muscle & 0.00027 & 0.00452 & - & - & - & Strungaru et al., 2020 \\
\hline
\end{tabular}




\section{$908 \quad$ Table 8}

909 Metal contents $(\mathrm{mg} / \mathrm{kg})$ in different feed of fish and crustacean measured by several researchers in their studies.

\begin{tabular}{|c|c|c|c|c|c|c|c|c|}
\hline \multirow[t]{2}{*}{ Feed types } & \multirow[t]{2}{*}{ Sampling sites } & \multirow[t]{2}{*}{ Details } & \multicolumn{5}{|l|}{ Heavy metals } & \multirow[t]{2}{*}{ References } \\
\hline & & & $\mathrm{Cd}$ & $\mathrm{Pb}$ & $\mathrm{Ni}$ & $\mathrm{Cu}$ & $\mathrm{Cr}$ & \\
\hline Fish feed & $\begin{array}{l}\text { Mymensingh, } \\
\text { Bangladesh }\end{array}$ & $\begin{array}{l}3 \text { commercial pangas } \\
\text { feeds }\end{array}$ & $\begin{array}{l}\text { Feed 1: } 0.38 \pm 0.04 \\
\text { Feed 2: } 0.42 \pm 0.18 \\
\text { Feed 3: } 0.90 \pm 0.59\end{array}$ & $\begin{array}{l}\text { Feed 1: } 0.18 \pm 0.13 \\
\text { Feed 2: } 0.0 \pm 0.0 \\
\text { Feed 3: } 0.0 \pm 0.0\end{array}$ & $\begin{array}{l}\text { Feed 1: } 684.3 \pm 182.4 \\
\text { Feed 2: } 454.3 \pm 231.7 \\
\text { Feed 3: } 207.27 \pm 86.0\end{array}$ & $\begin{array}{l}\text { Feed 1: } 5.19 \pm 0.38 \\
\text { Feed 2: } 5.67 \pm 0.25 \\
\text { Feed 3: } 5.88 \pm 0.03\end{array}$ & $\begin{array}{l}\text { Feed 1: } 0.0 \pm 0.0 \\
\text { Feed 2: } 0.0 \pm 0.0 \\
\text { Feed 3: } 0.0 \pm 0.0\end{array}$ & Present study \\
\hline Shrimp feed & Bangladesh & 12 feeds & $<0.1-2.1$ & $<0.1-8.57$ & - & - & - & Shamshad et al., 2009 \\
\hline Fish feed & $\begin{array}{l}\text { Chaharmahal-va- } \\
\text { Baghtiari province, Iran }\end{array}$ & $\begin{array}{l}\text { Commercial rainbow } \\
\text { trout feed }\end{array}$ & $0.0-1.213$ & $0.992-5.317$ & $0.0-3.904$ & $4.146-13.51$ & $0.0-2.968$ & Fallah et al., 2011 \\
\hline Fish feed & $\begin{array}{l}\text { Makurdi metropolis, } \\
\text { Nigeria }\end{array}$ & Synthetic 2 feeds & $\begin{array}{l}\text { Diet 1: } 0.03 \\
\text { Diet 2: } 0.02\end{array}$ & $\begin{array}{l}\text { Diet } 1: 0.348 \\
\text { Diet 2: } 0.375\end{array}$ & $\begin{array}{l}\text { Diet 1: } 0.092 \\
\text { Diet 2: } 0.008\end{array}$ & $\begin{array}{l}\text { Diet 1: } 0.157 \\
\text { Diet 2: } 0.204\end{array}$ & - & Anhwange et al., 2012 \\
\hline Prawn feed & $\begin{array}{l}\text { Satkhira, Bagerhat, } \\
\text { Dhaka, Bangladesh }\end{array}$ & 12 feeds & $0.07-2.11$ & $3.27-4.59$ & - & - & $<0.54$ & Islam et al., 2017 \\
\hline Fish feed & Bangladesh & 10 feeds & $1.17-2.0$ & $3.83-21.2$ & $3.5-7.16$ & $5.17-21.67$ & $2.1-16.49$ & Saha et al., 2018 \\
\hline Fish feed & $\begin{array}{l}\text { South western region, } \\
\text { Bangladesh }\end{array}$ & Local fish feeds & $0.29 \pm 0.08$ & $8.49 \pm 3.66$ & - & - & $8.57 \pm 3.47$ & Sabbir et al., 2018 \\
\hline Fish feed & Hongkong, China & $\begin{array}{l}\text { Fermented } 2 \text { diets (Nile } \\
\text { tilapia \& Jade perch) }\end{array}$ & $\begin{array}{l}\text { Diet 1: } 0.011 \\
\text { Diet 2: } 0.026\end{array}$ & $\begin{array}{l}\text { Diet 1: } 0.081 \\
\text { Diet 2: } 1.745\end{array}$ & - & $\begin{array}{l}\text { Diet 1: } 0.851 \\
\text { Diet 2: } 0.851\end{array}$ & $\begin{array}{l}\text { Diet 1: } 0.163 \\
\text { Diet 2: } 0.300\end{array}$ & Mo et al., 2019 \\
\hline Fish feed & UAE & 3 types of pellet diets & $\begin{array}{l}\text { Diet 1: } 0.20 \\
\text { Diet 2: } 0.07 \\
\text { Diet 3: } 0.23\end{array}$ & $\begin{array}{l}\text { Diet 1: } 0.14 \\
\text { Diet 2: } 3.20 \\
\text { Diet 3: } 0.27\end{array}$ & - & - & - & Ali et al., 2019 \\
\hline
\end{tabular}




\section{Figure captions}

912 Fig. 1 Map represents the sampling sites of present study (created by ArcGIS v. 10.7.1).

913 Fig. 2 Mean $( \pm \mathrm{SEM})$ concentration of the Cadmium (Cd), Lead (Pb), Nickel $(\mathrm{Ni})$ and Copper

$914(\mathrm{Cu})$ in pangas collected from farms of Mymensingh district during pre- and post-monsoon.

915 Error bars with stars are significantly different within each metal $(t$-test, $p<0.05)$. Red

916 disconnected lines with values indicate maximum acceptable limit of the studied metals where

917 their superscript a, b, c represents FAO/WHO (1989), USFDA (1993), WHO (2011),

918 respectively.

919 Fig. 3A (i-v) Mean ( $\pm \mathrm{SEM}$ ) concentration of the $\mathrm{Cd}, \mathrm{Pb}, \mathrm{Ni}, \mathrm{Cu}, \mathrm{Cr}$ in feed and pangas 920 collected from farms of Muktagacha, Trishal and Bhaluka of Mymensingh district during premonsoon. Bars with stars are significantly different within feed and pangas (ANOVA, $p<0.05$ ). Red disconnected lines with values indicate maximum permissible limit of the studied metals where superscript a, b, c on feed values represent FAO/WHO (1984), EC (2003), WHO (1985), respectively; similarly, on pangas define FAO/WHO (1989), USFDA (1993), WHO (2011), respectively.

Fig. 3B (i-iv) Mean $( \pm \mathrm{SD})$ concentration of the $\mathrm{Cd}, \mathrm{Pb}, \mathrm{Ni}$ and $\mathrm{Cu}$ in feed and pangas collected from farms of Muktagacha, Trishal and Bhaluka upazilas of Mymensingh district during postmonsoon. Bars with stars are significantly different within feed and pangas (ANOVA, $p<0.05$ ). Red disconnected lines with values indicate maximum permissible limit of the studied metals where superscript a, b represents on feed values represent FAO/WHO (1984), EC (2003), respectively; similarly, on pangas define FAO/WHO (1989), USFDA (1993), respectively.

932 Fig. 4 Boxplots represent estimated dietary intake (EDI) (mg/day) of studied metals from 933 Muktagacha, Trishal, and Bhaluka (i-iii) and Mymensingh district (iv) in 2017 calculated from 934 studied pangas sample. Red disconnected lines with values indicate a tolerable daily intake 935 limit of studied metals where superscript a, b, c; denotes provisional tolerable monthly intake 936 (JECFA, 2019), provisional tolerable weekly intake (JECFA, 2019; Lin et al. 2004), 937 provisional tolerable daily intake (FAO, 2006), respectively.

938 Fig. 5 Boxplots depict target hazard quotients (THQ) of studied metals from Muktagacha, 939 Trishal and Bhaluka (i-iii) and Mymensingh district (iv) in 2017 calculated from the metal 940 concentrations of studied pangas sample. Red dashed line indicates benchmark of noncarcinogenic hazardous condition (USEPA, 2011). 
942 Fig. 6 Violin plots illustrate carcinogenic risk (CR) of studied lead ( $\mathrm{Pb}$ ) from Mymensingh 943 district (Muktagacha, Trishal and Bhaluka) in 2017 calculated from studied pangas sample.

944 Red dashed line indicates benchmark of carcinogenic risk limit (USEPA 2010).

945 Fig. 7 Biplot of tested heavy metals in pangas of studied areas by principal component analysis

946 (PCA) where right-bottom corner of this figure displayed the scree plot of this PCA with two 947 drastic slopes and eigen values.

948 Fig. 8 Two-way cluster analysis of metal contents in pangas among sampling sites during pre949 and post-monsoon of 2017, where yellow color indicates the lowest concentrations of each 950 metal and dark blue represents the highest concentrations. Color palette from yellow to dark 951 blue represents increasing trends of metal concentrations. The rightmost corner of the figure 952 indicates the distance graph that plotted distances beneath the dendrogram. Each farm with 953 three values represents three tested tissue samples (gill, liver and muscle). 


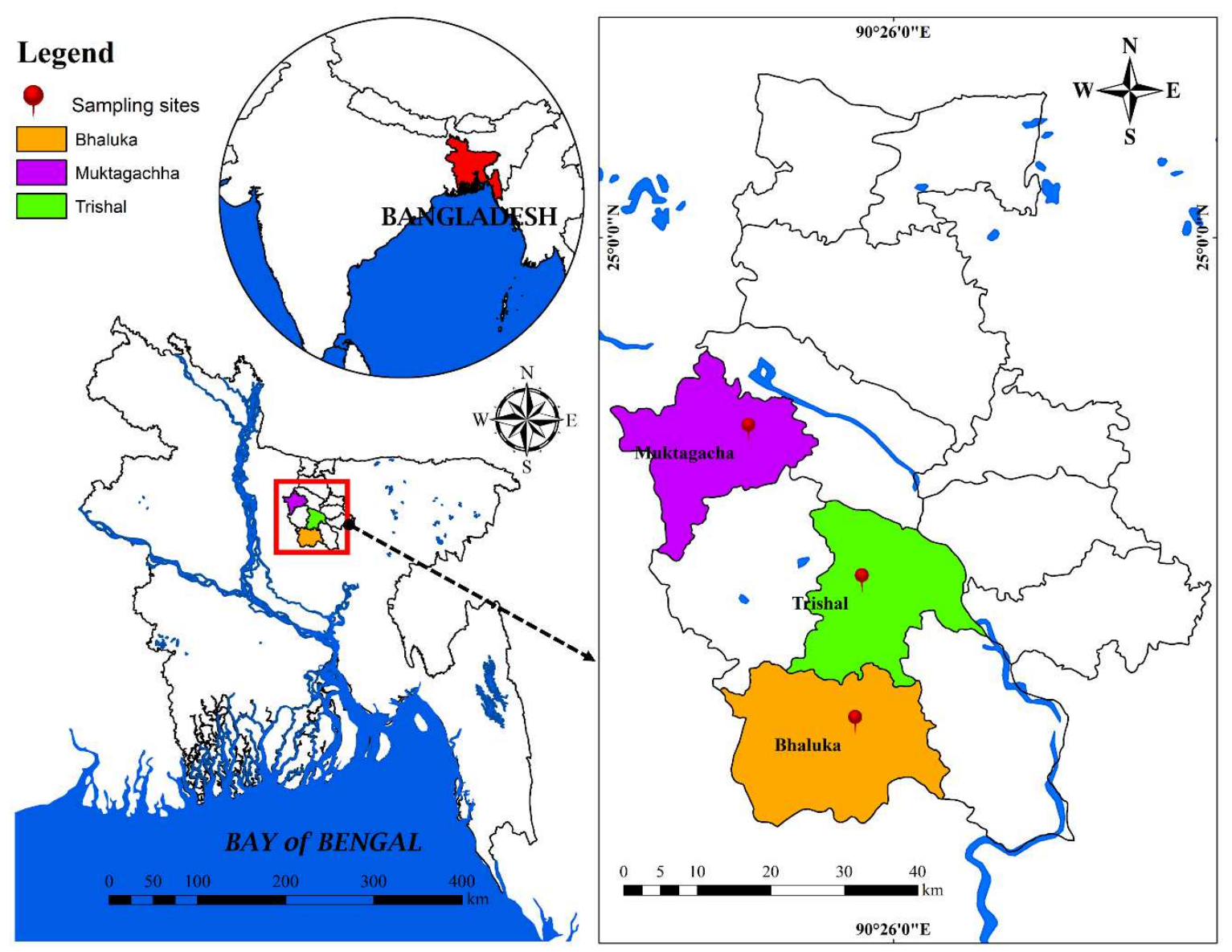

955 Fig. 1

956 


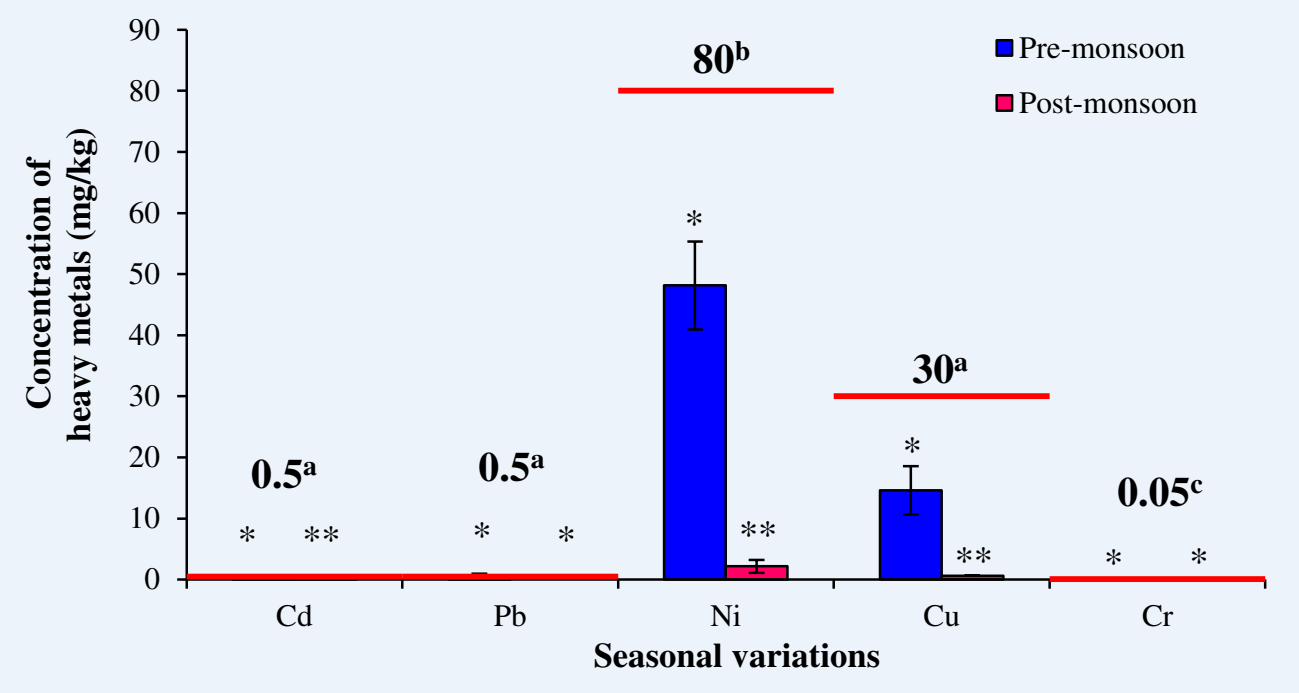

$957 \quad$ Fig. 2

958 


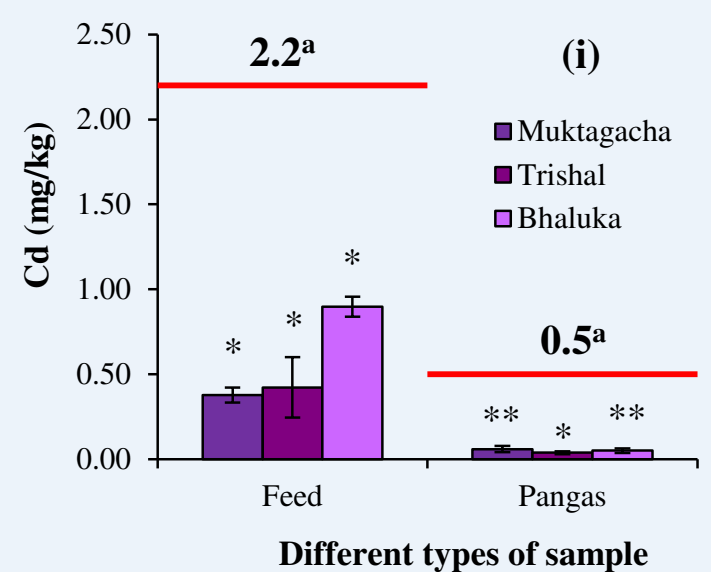

Different types of sample

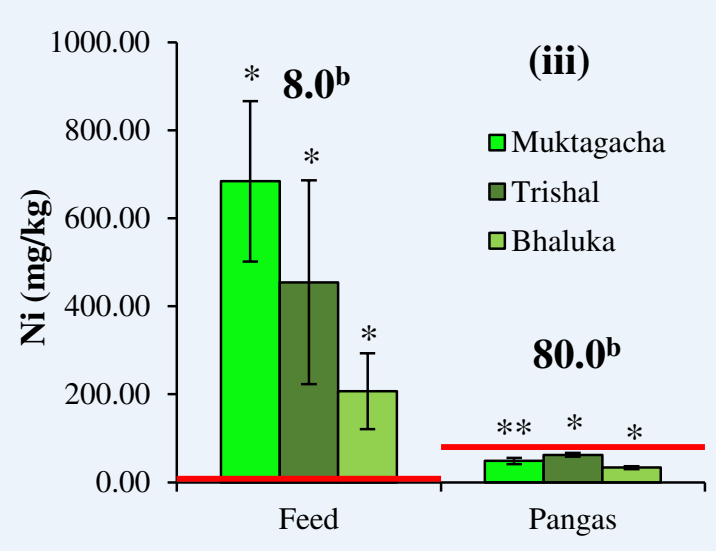

Different types of sample

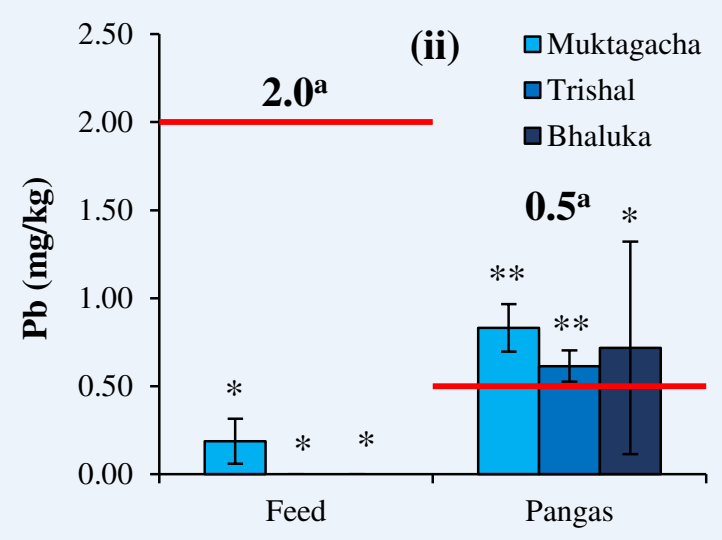

Different types of sample

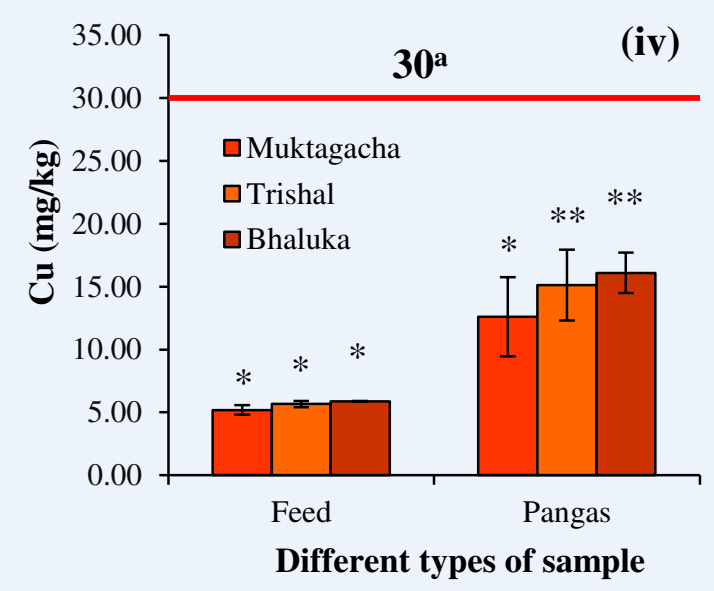

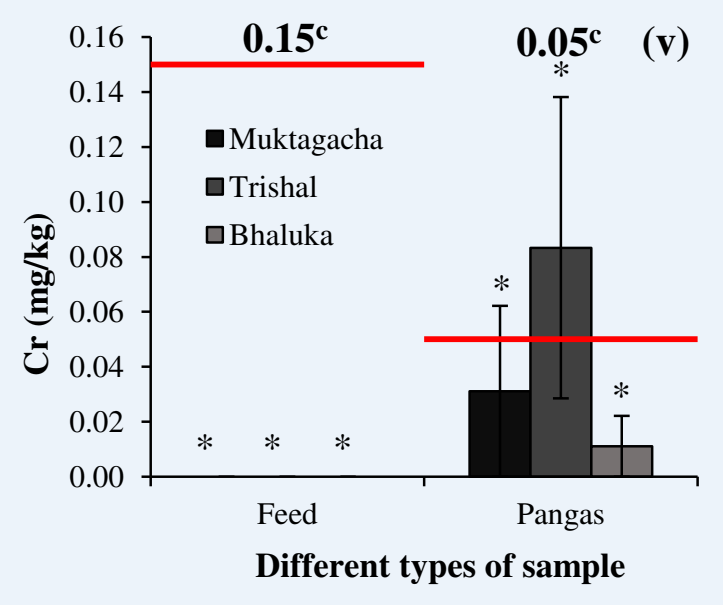



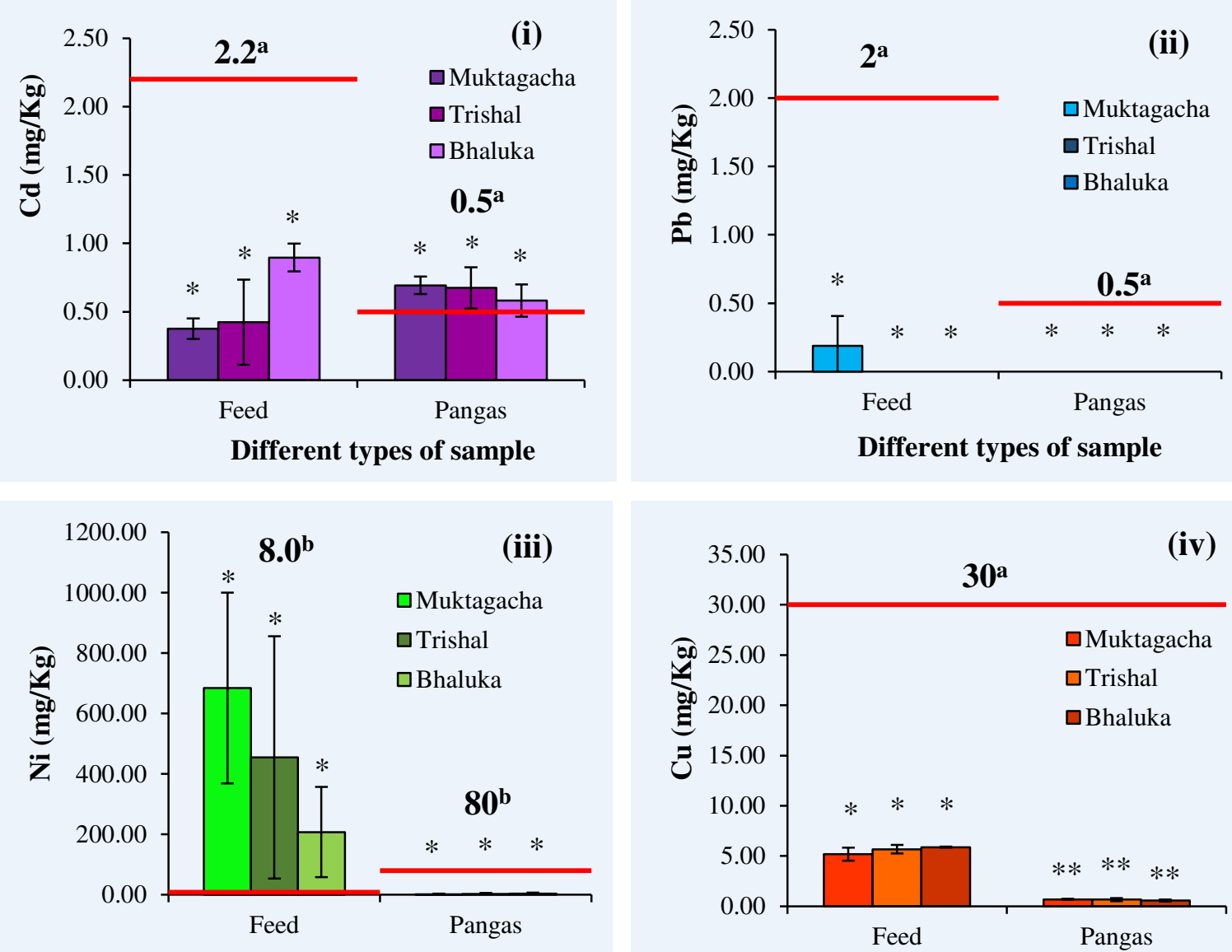

Different types of sample

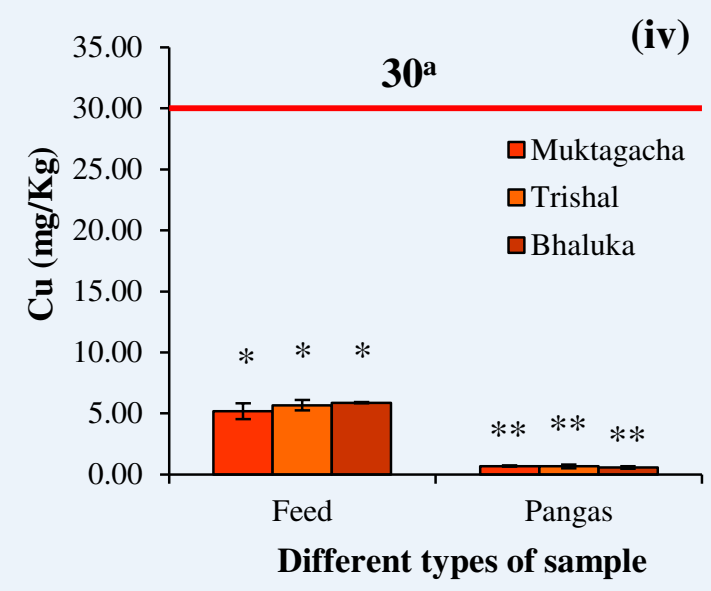

\section{$961 \quad$ Fig. 3B}




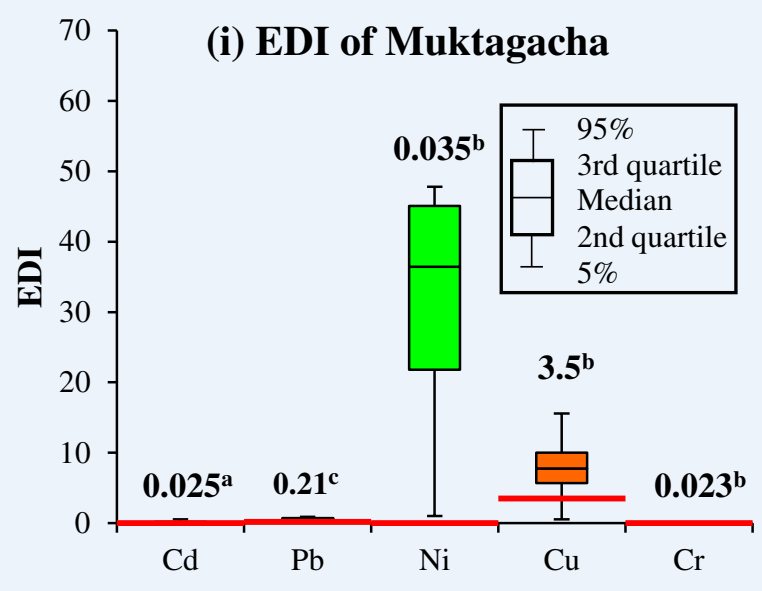

Heavy metals

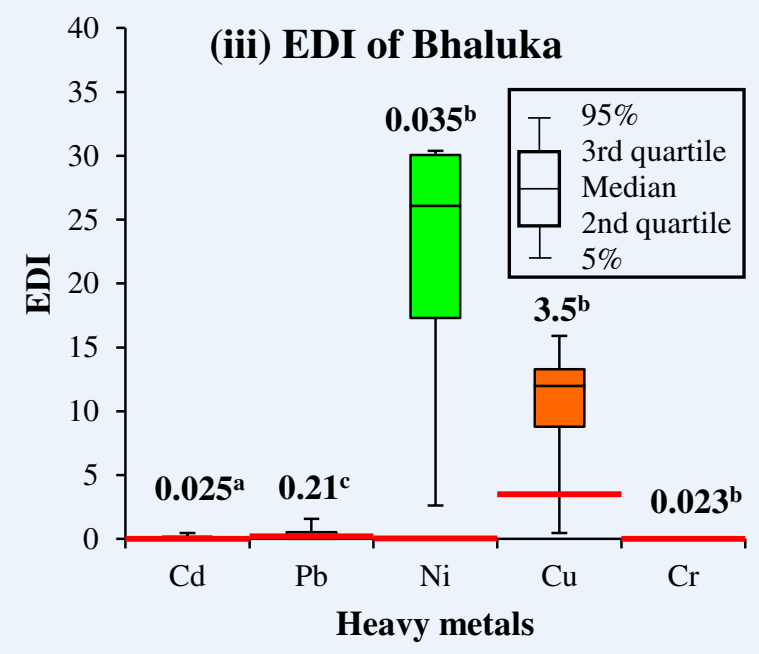

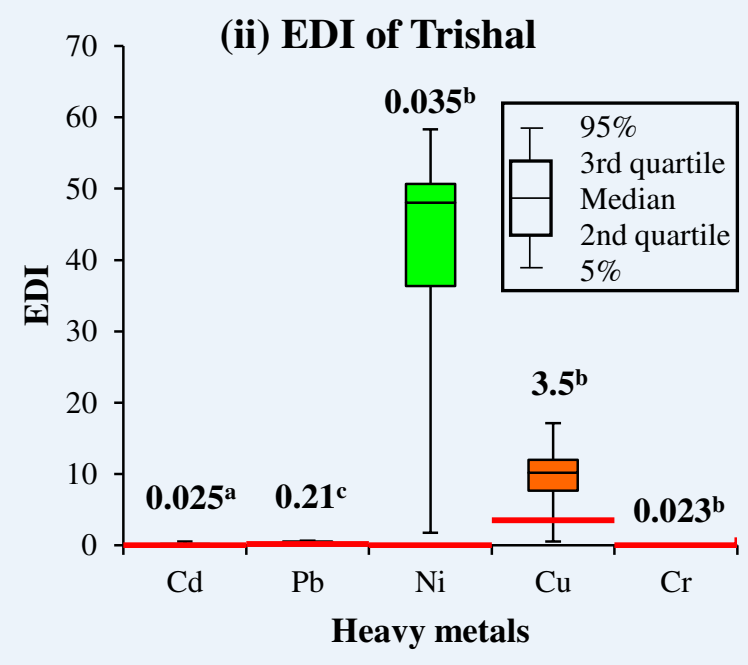

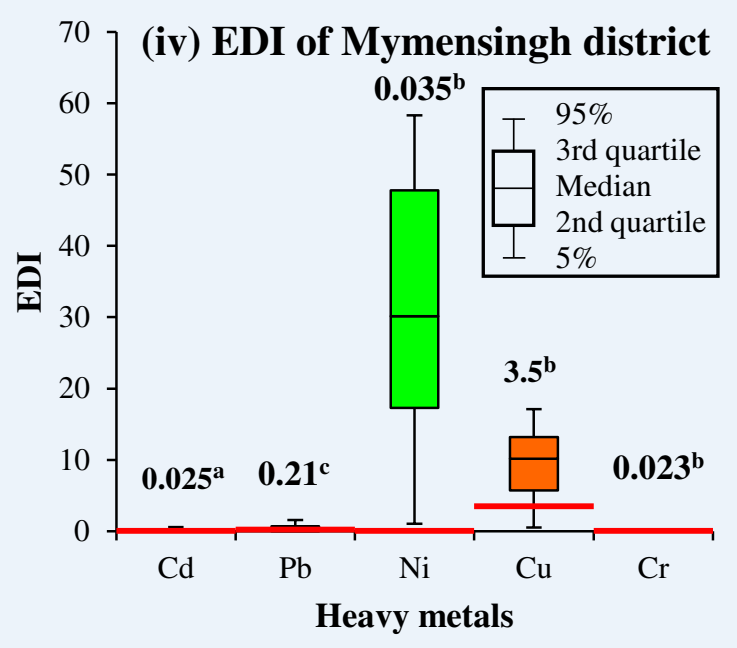

Fig. 4

964 

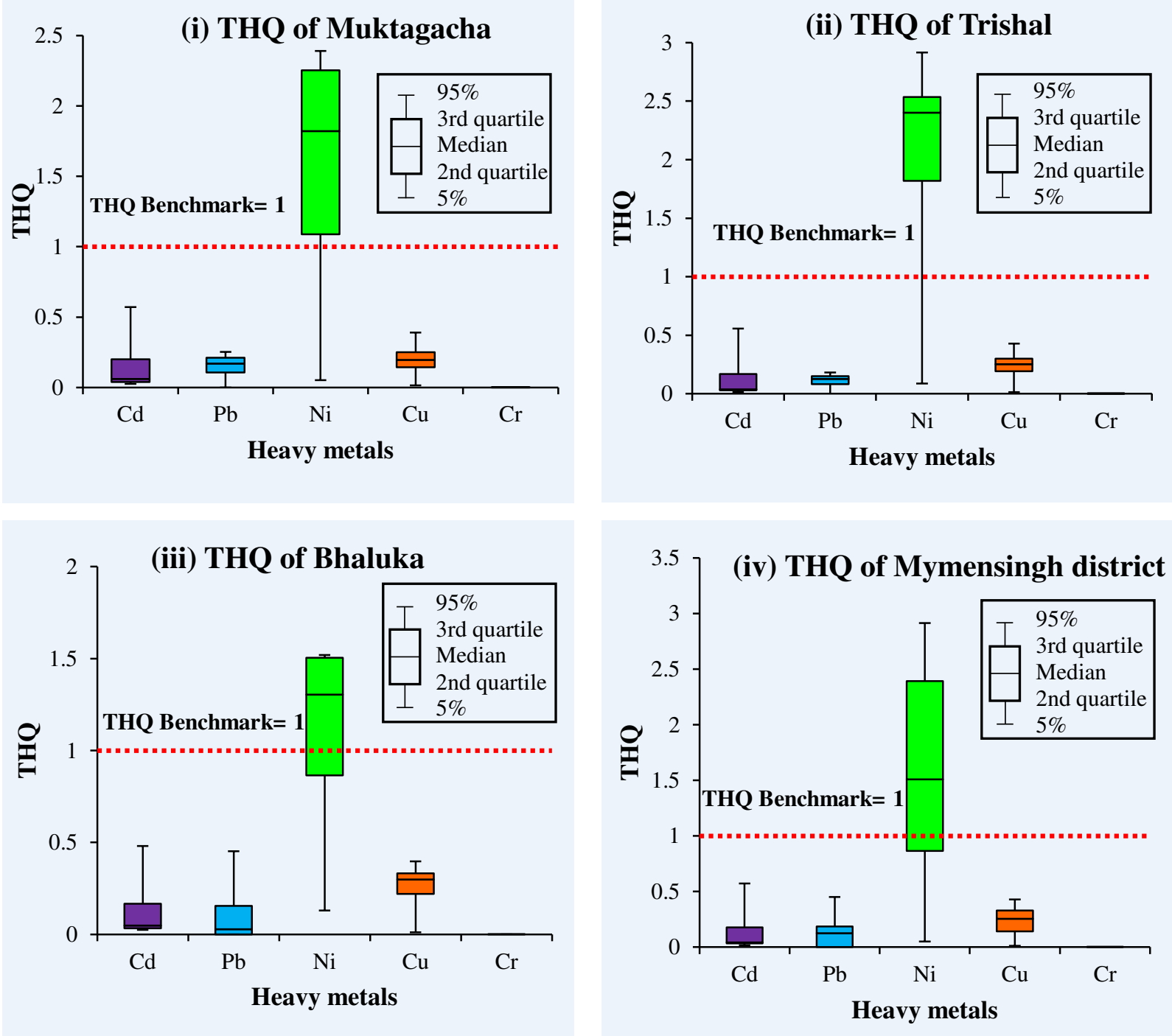

Fig. 5

966 


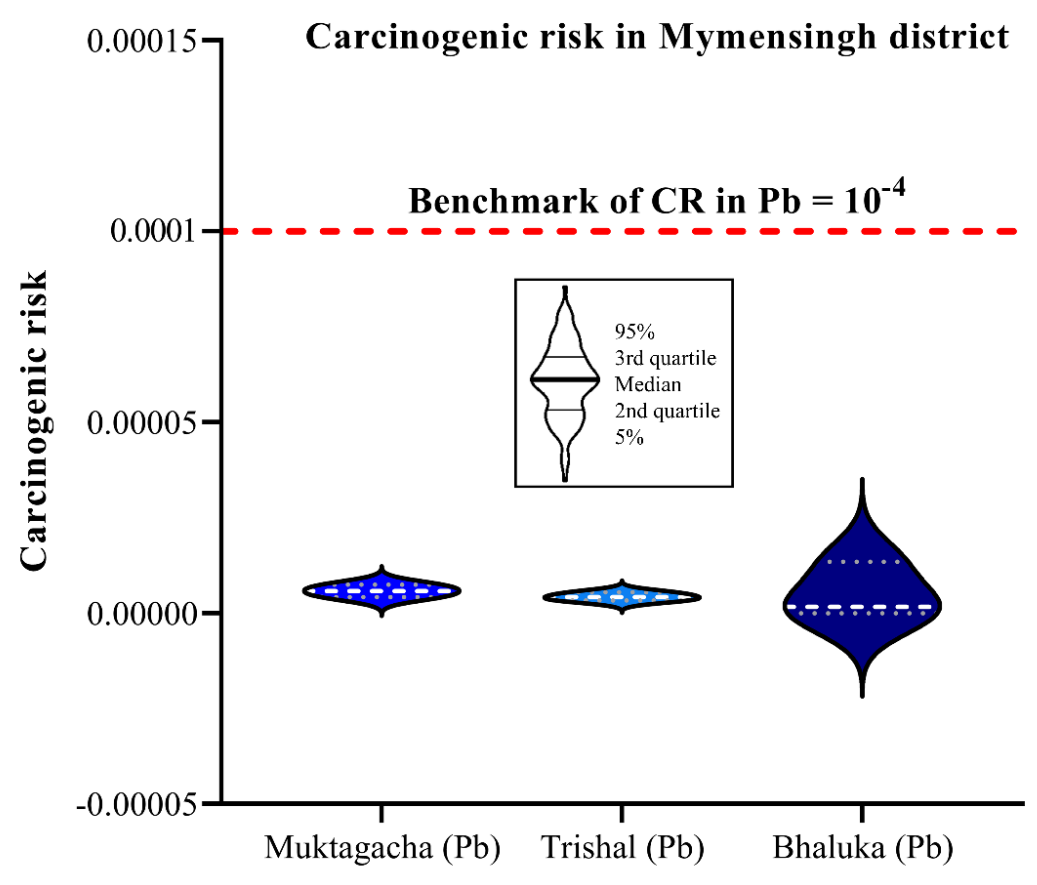

967

$\mathrm{Pb}$ in studied areas

$968 \quad$ Fig. 6

969 


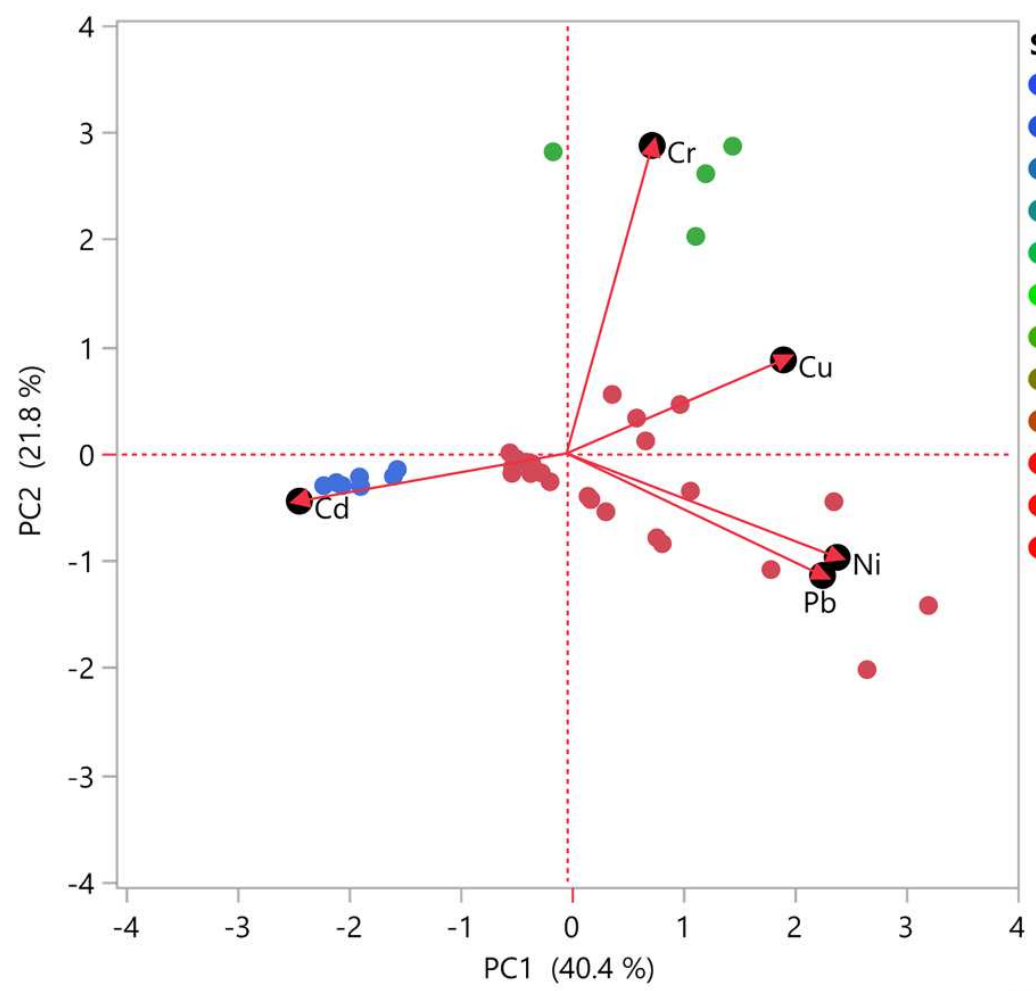

\section{Sampling sites}

- Bhaluka_Farm 7_Pre-monsoon

- Bhaluka_Farm 8_Pre-monsoon

- Bhaluka_Farm 9_Pre-monsoon

- Bhaluka_Farm 12_Post-monsoon

- Muktagacha_Farm 1_Pre-monsoon

- Muktagacha_Farm 2_Pre-monsoon

- Muktagacha_Farm 3_Pre-monsoon

- Muktagacha_Farm 10_Post-monsoon

- Trishal_Farm 4_Pre-monsoon

- Trishal_Farm 5_Pre-monsoon

- Trishal_Farm 6_Pre-monsoon

- Trishal_Farm 11_Post-monsoon

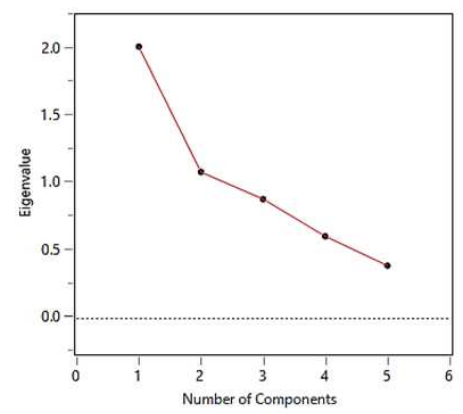

Fig. 7 


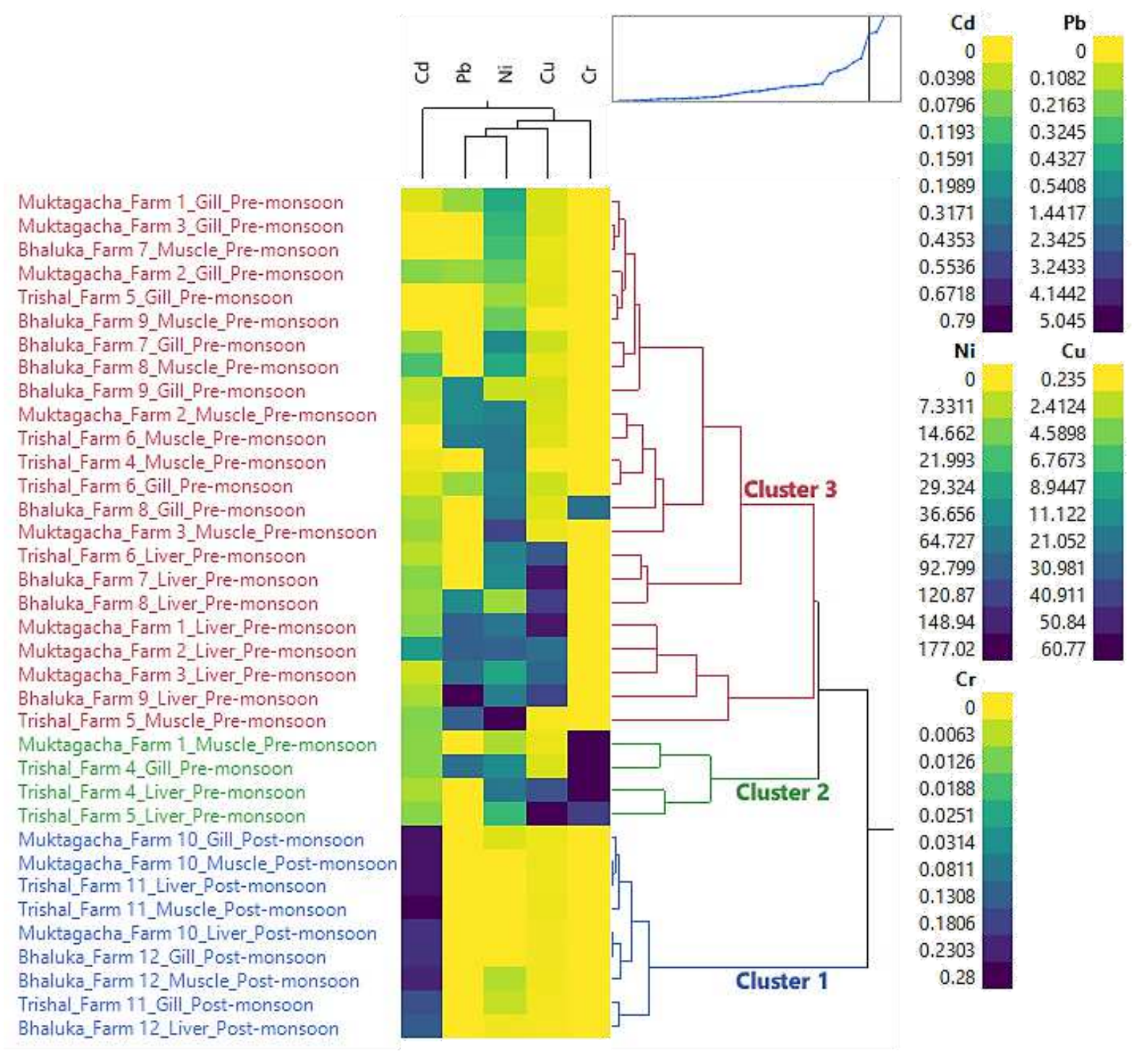

\section{$973 \quad$ Fig. 8}




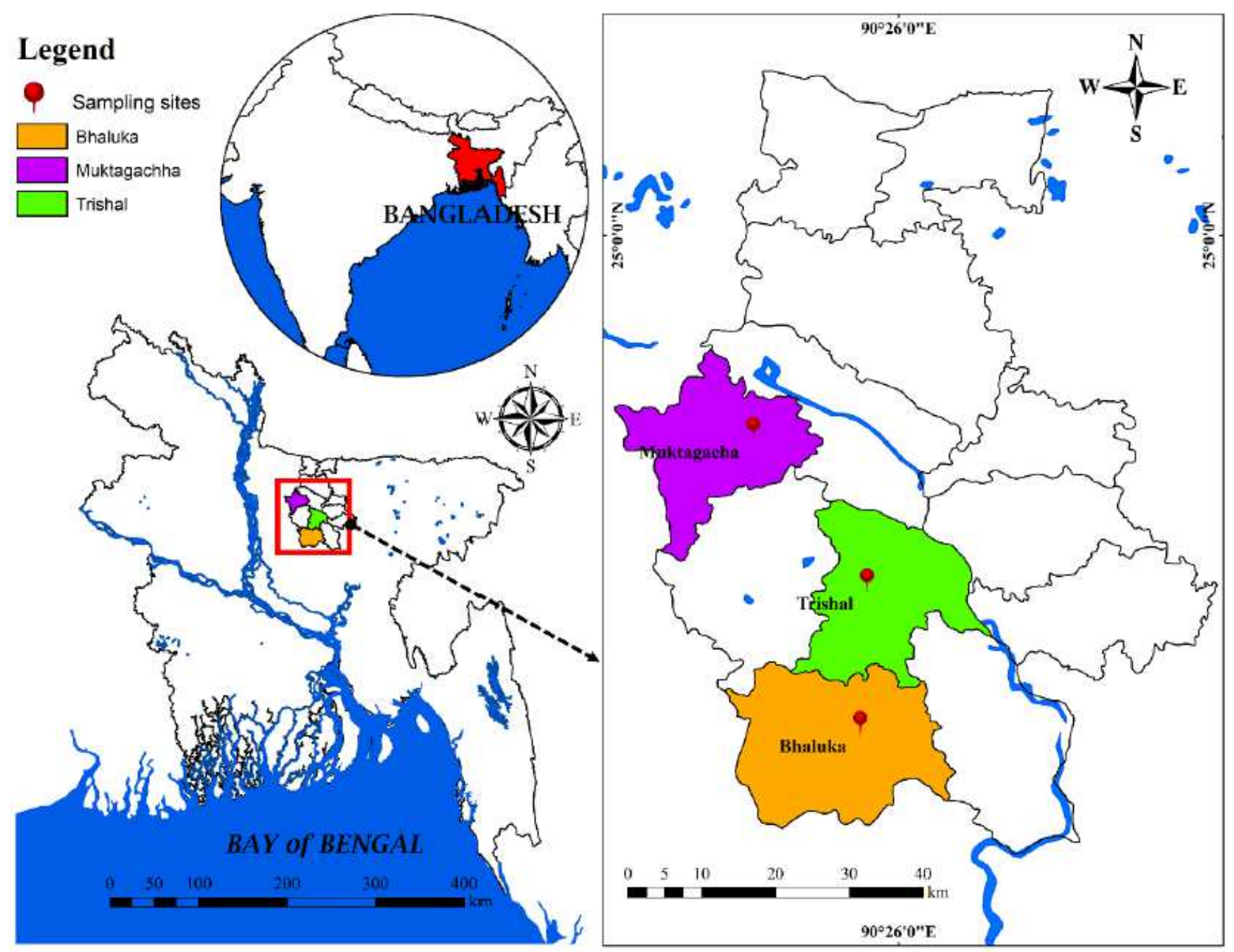

Figure 1

Map represents the sampling sites of present study (created by ArcGIS v. 10.7.1). Note: The designations employed and the presentation of the material on this map do not imply the expression of any opinion whatsoever on the part of Research Square concerning the legal status of any country, territory, city or area or of its authorities, or concerning the delimitation of its frontiers or boundaries. This map has been provided by the authors. 


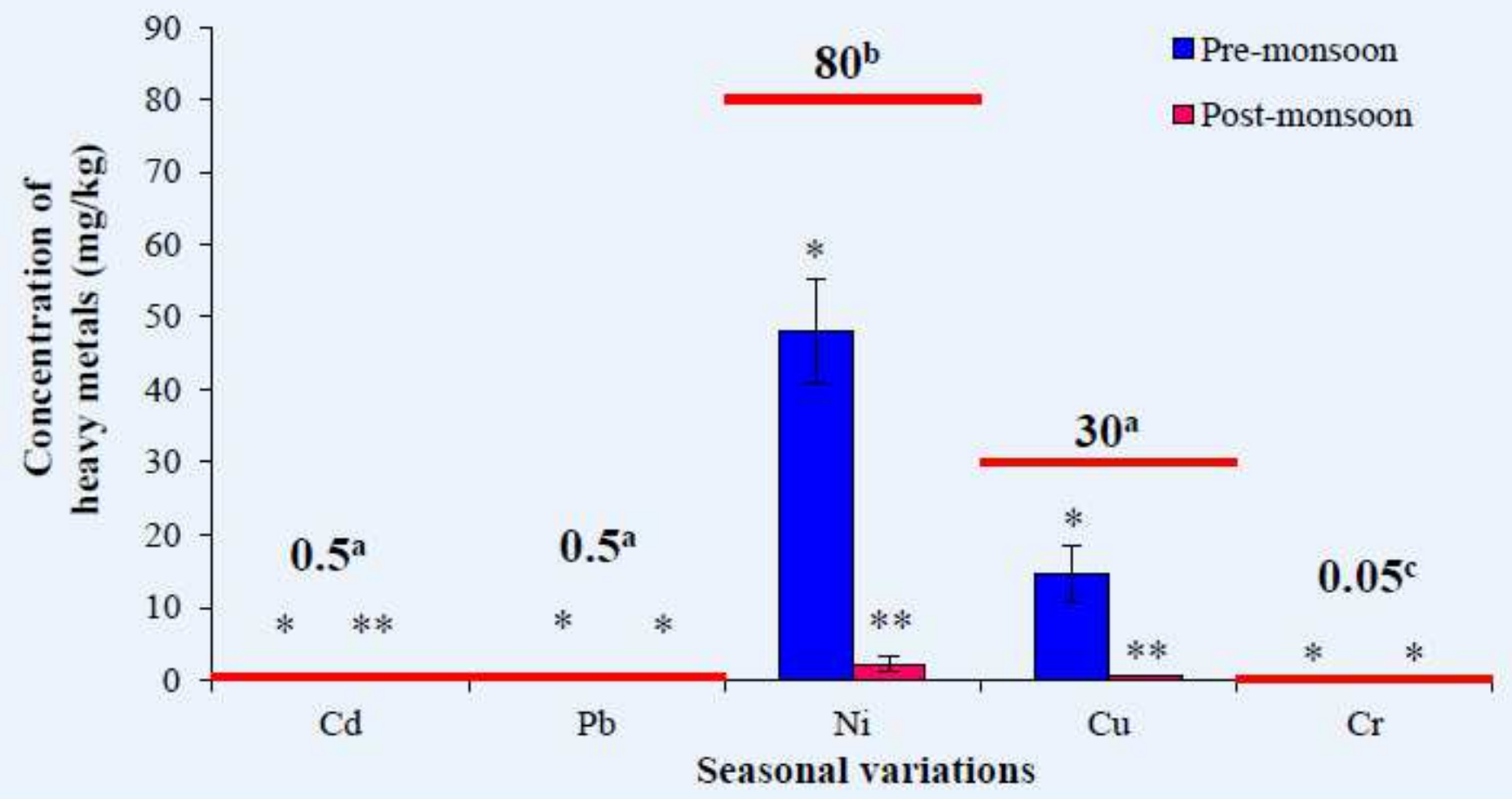

Figure 2

Mean ( \pm SEM) concentration of the Cadmium (Cd), Lead (Pb), Nickel (Ni) and Copper ( $\mathrm{Cu}$ ) in pangas collected from farms of Mymensingh district during pre- and post-monsoon. Error bars with stars are significantly different within each metal (t-test, $p<0.05)$. Red disconnected lines with values indicate maximum acceptable limit of the studied metals where their superscript $a, b, c$ represents FAO/WHO (1989), USFDA (1993), WHO (2011), respectively. 

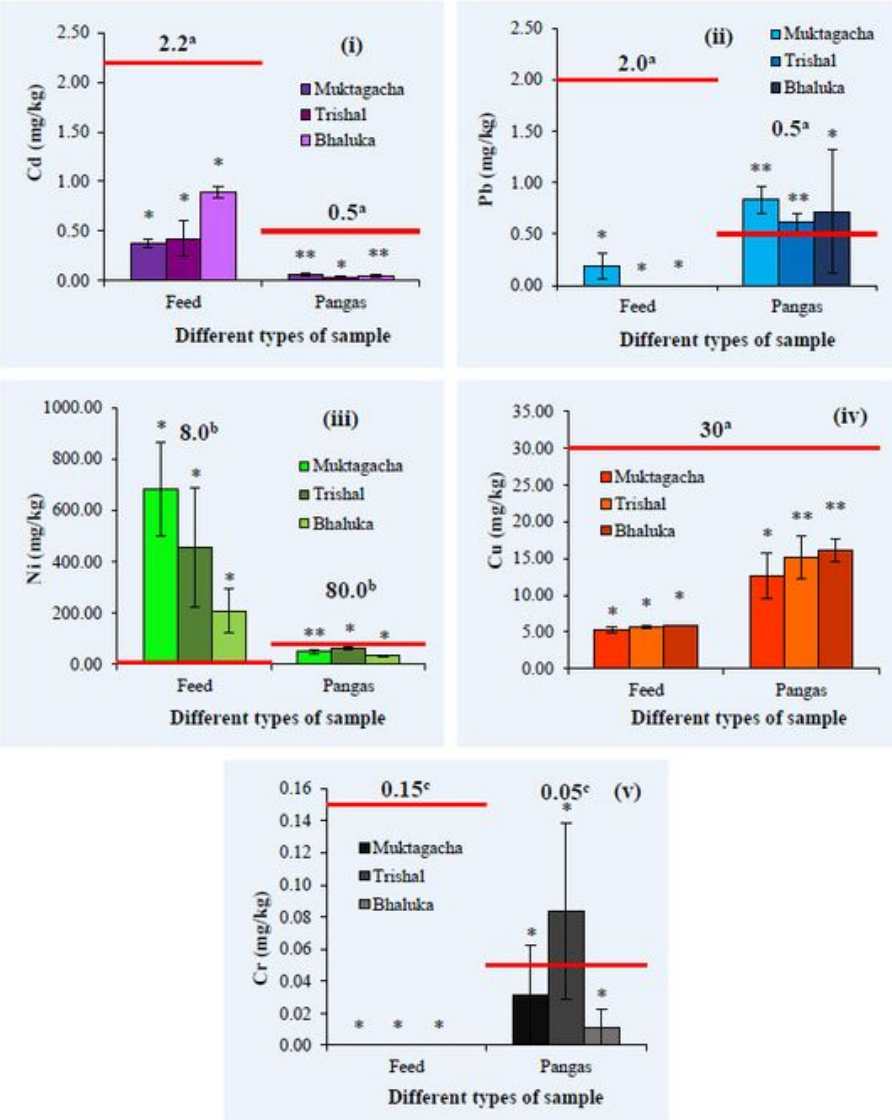

Fig. 3A
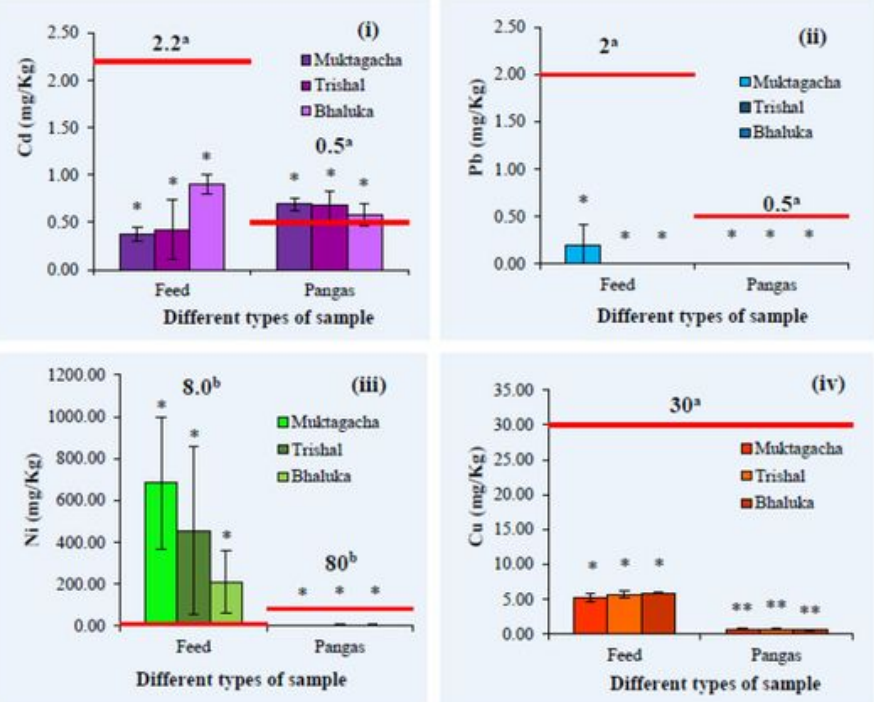

Fig. 3B

\section{Figure 3}

A (i-v) Mean ( \pm SEM) concentration of the $\mathrm{Cd}, \mathrm{Pb}, \mathrm{Ni}, \mathrm{Cu}, \mathrm{Cr}$ in feed and pangas collected from farms of Muktagacha, Trishal and Bhaluka of Mymensingh district during pre monsoon. Bars with stars are significantly different within feed and pangas (ANOVA, $p<0.05$ ). Red disconnected lines with values indicate maximum permissible limit of the studied metals where superscript $a, b, c$ on feed values represent FAO/WHO (1984), EC (2003), WHO (1985), respectively; similarly, on pangas define FAO/WHO 
(1989), USFDA (1993), WHO (2011), respectively. B (i-iv) Mean ( \pm SD) concentration of the Cd, Pb, Ni and $\mathrm{Cu}$ in feed and pangas collected from farms of Muktagacha, Trishal and Bhaluka upazilas of Mymensingh district during post monsoon. Bars with stars are significantly different within feed and pangas (ANOVA, $p<0.05$ ). Red disconnected lines with values indicate maximum permissible limit of the studied metals where superscript $a$, b represents on feed values represent FAO/WHO (1984), EC (2003), respectively; similarly, on pangas define FAO/WHO (1989), USFDA (1993), respectively.

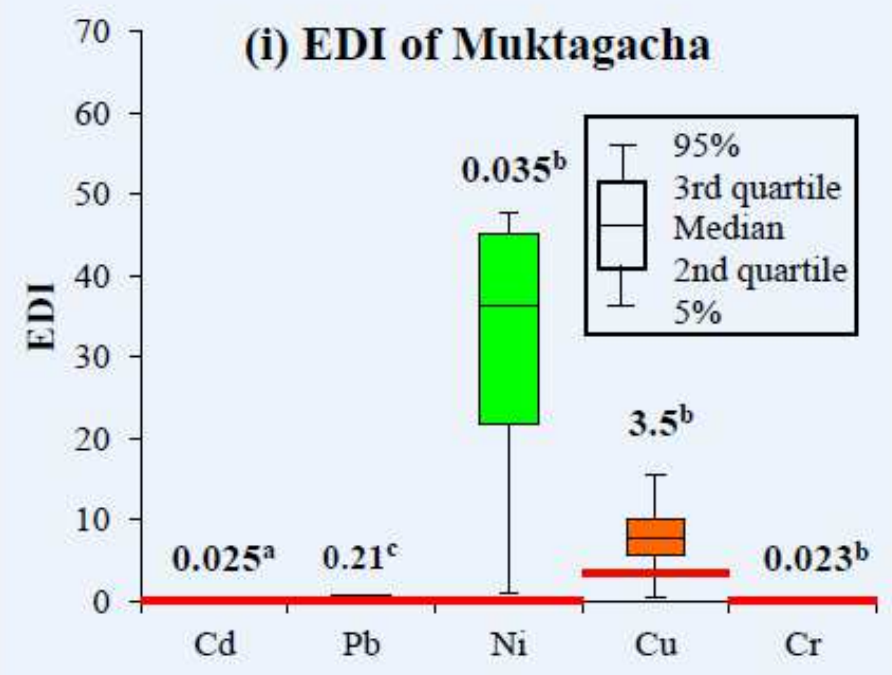

Heavy metals
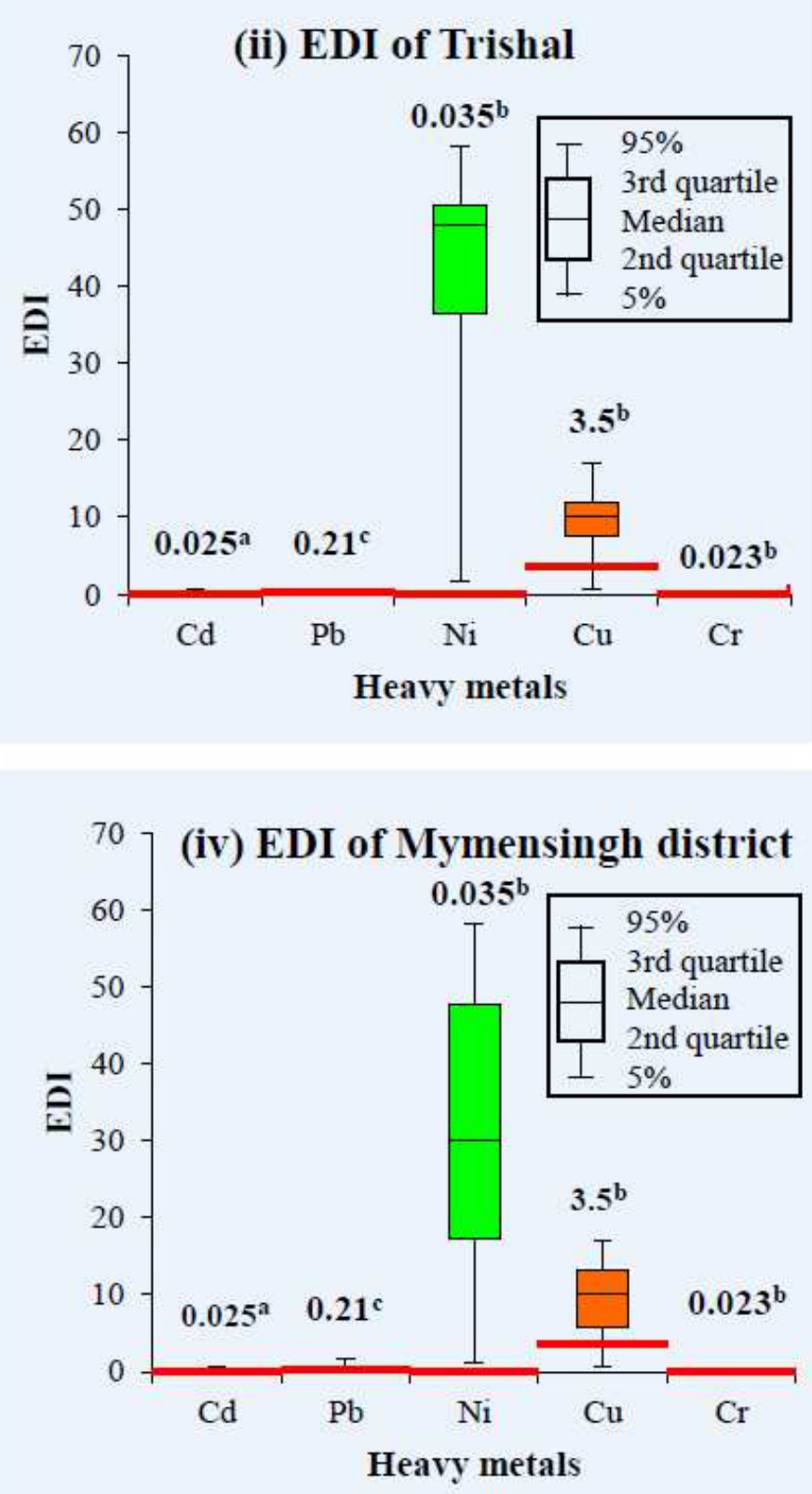

\section{Figure 4}

Boxplots represent estimated dietary intake (EDI) (mg/day) of studied metals from Muktagacha, Trishal, and Bhaluka (i-iii) and Mymensingh district (iv) in 2017 calculated from studied pangas sample. Red disconnected lines with values indicate a tolerable daily intake limit of studied metals where superscript 
a, b, c; denotes provisional tolerable monthly intake (JECFA, 2019), provisional tolerable weekly intake (JECFA, 2019; Lin et al. 2004), provisional tolerable daily intake (FAO, 2006), respectively.
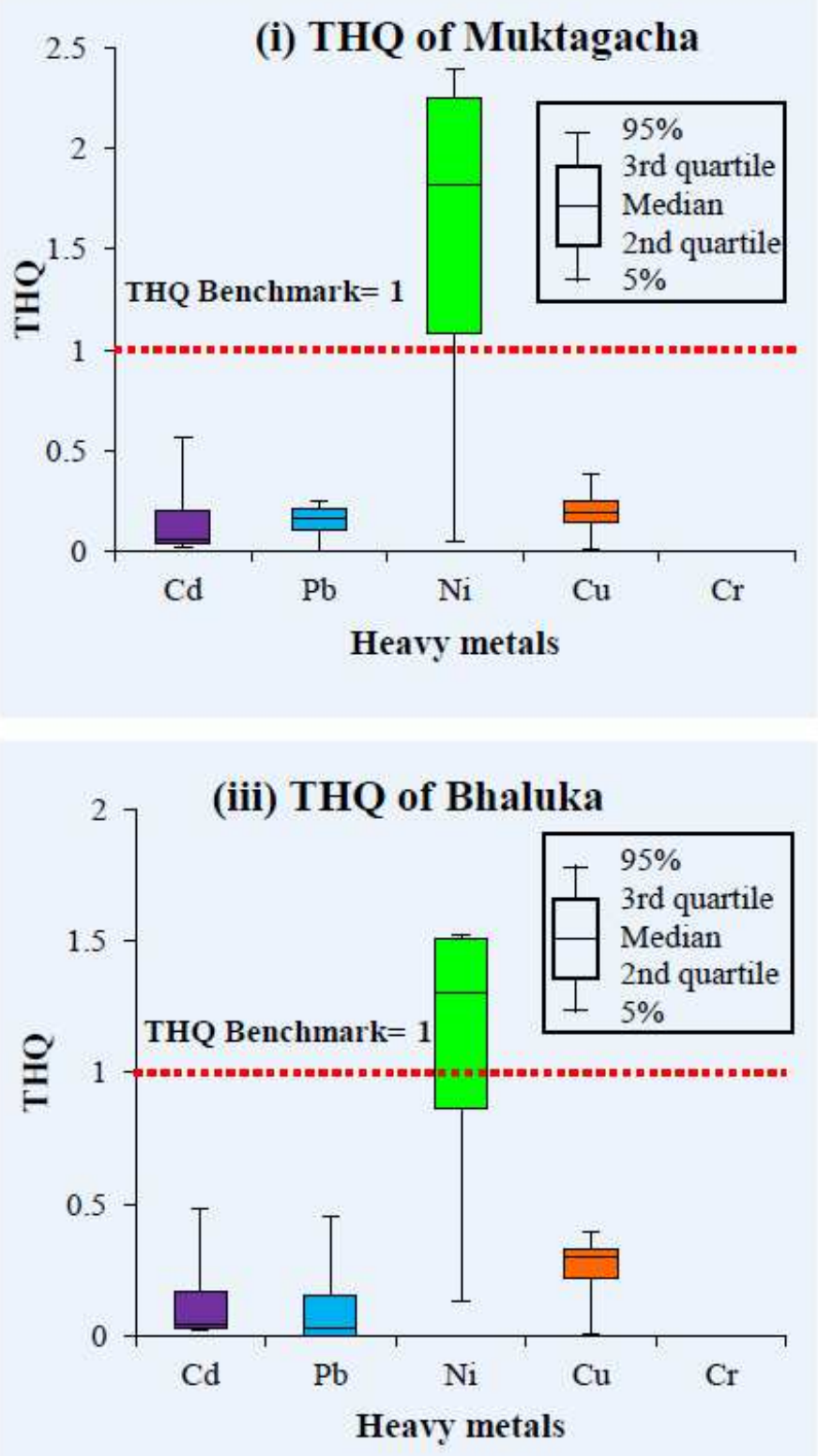
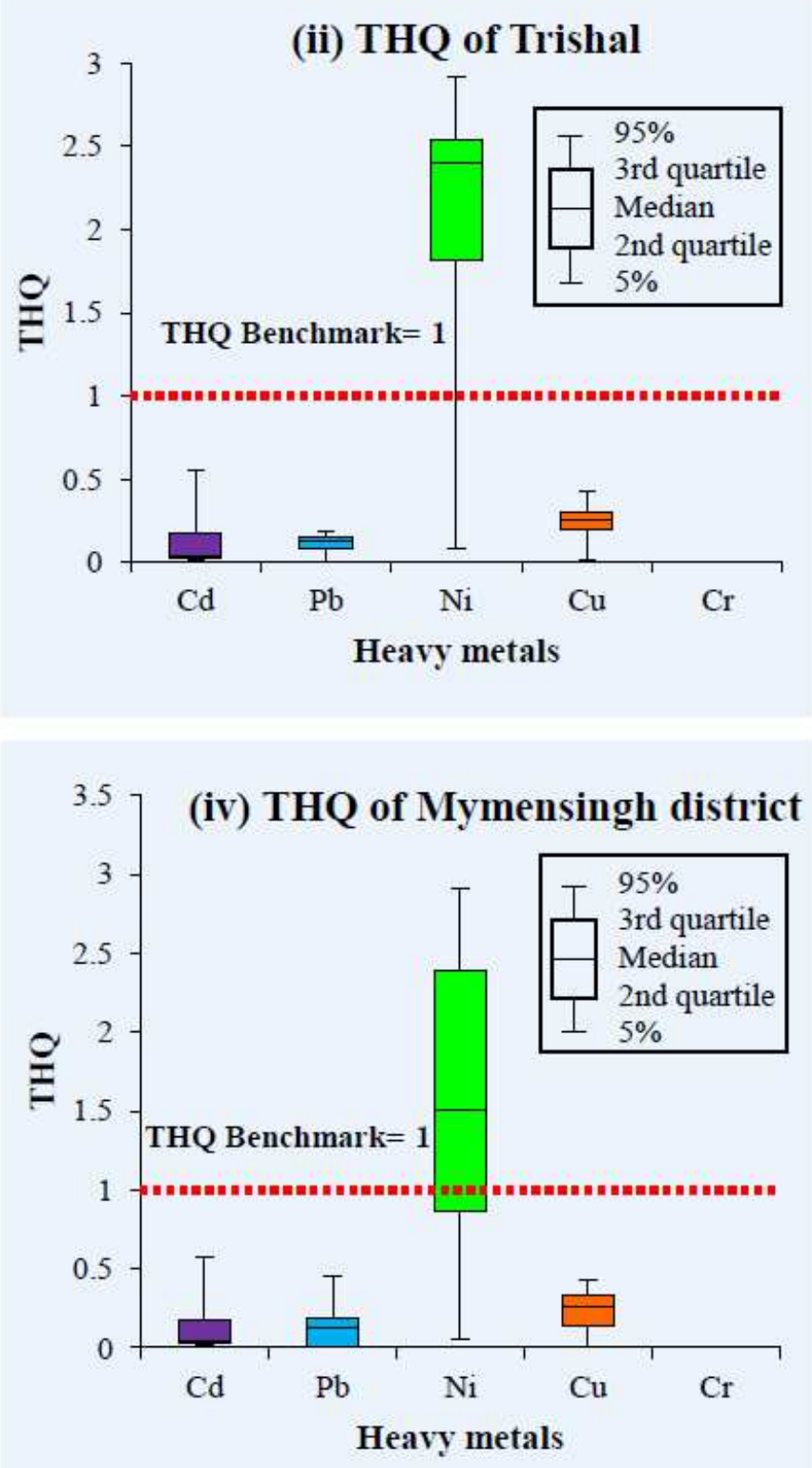

Figure 5

Boxplots depict target hazard quotients (THQ) of studied metals from Muktagacha, Trishal and Bhaluka (i-iii) and Mymensingh district (iv) in 2017 calculated from the metal concentrations of studied pangas sample. Red dashed line indicates benchmark of non-carcinogenic hazardous condition (USEPA, 2011). 


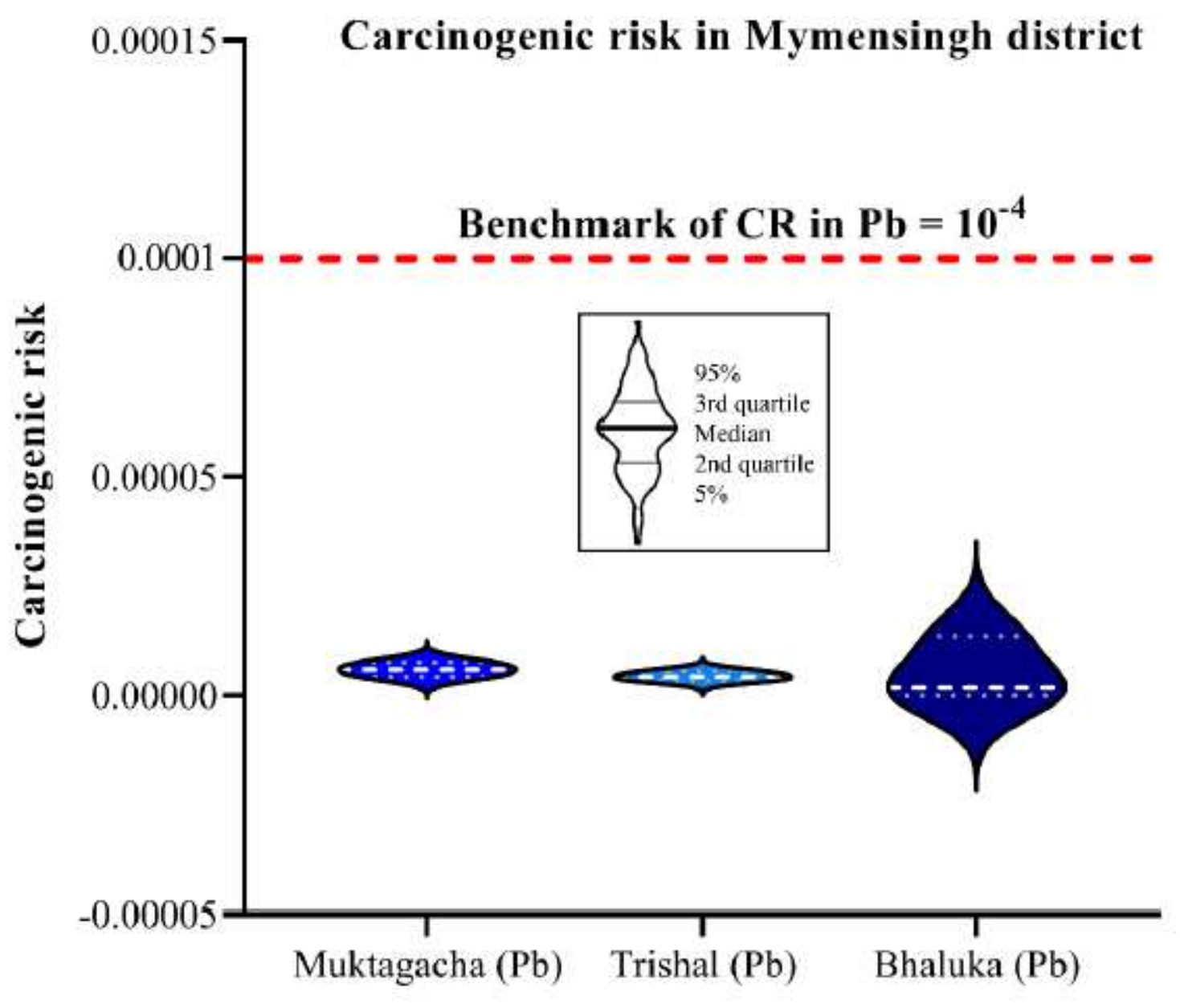

$\mathrm{Pb}$ in studied areas

Figure 6

Violin plots illustrate carcinogenic risk (CR) of studied lead $(\mathrm{Pb})$ from Mymensingh district (Muktagacha, Trishal and Bhaluka) in 2017 calculated from studied pangas sample. Red dashed line indicates benchmark of carcinogenic risk limit (USEPA 2010). 


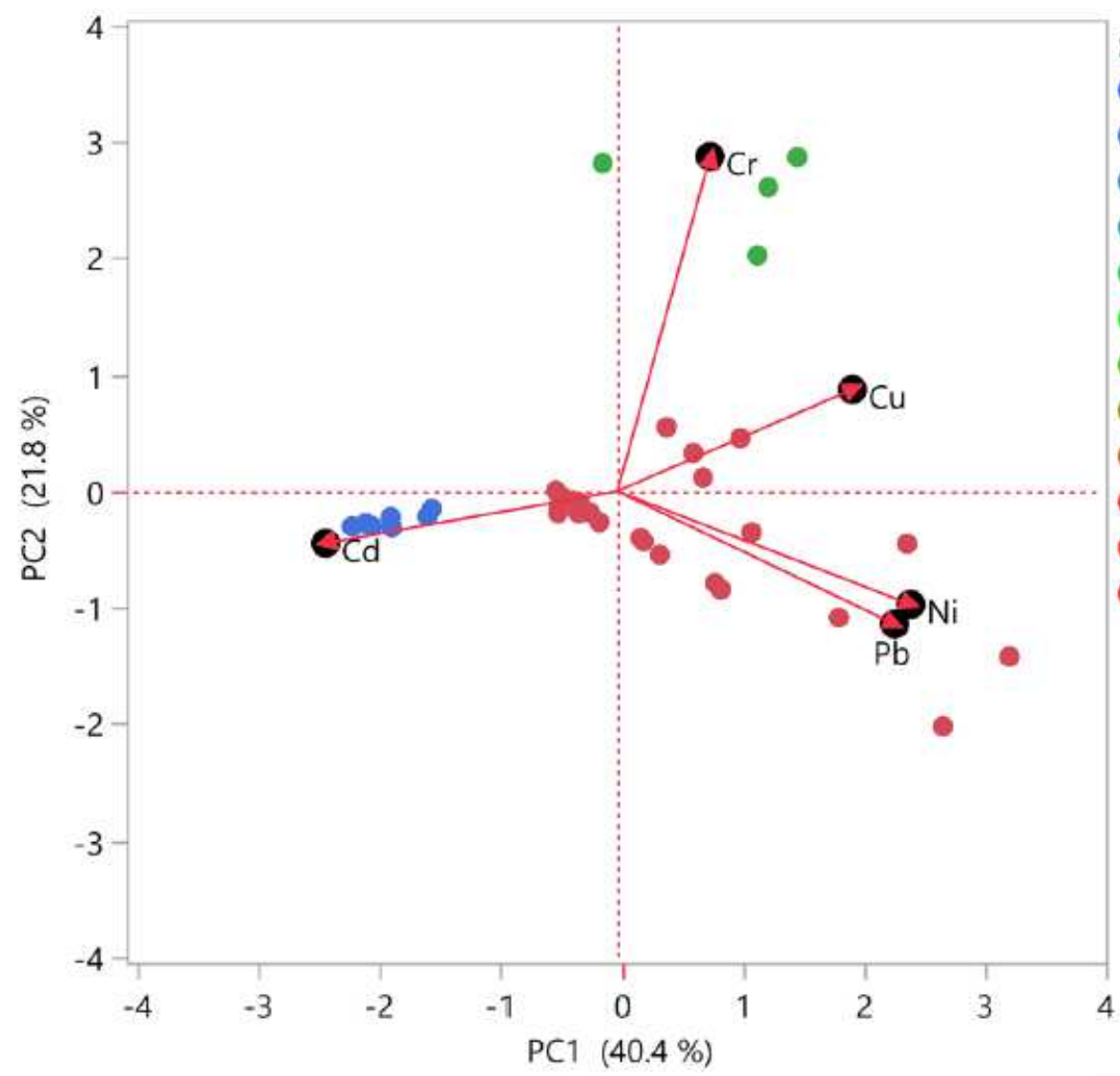

Sampling sites

Bhaluka_Farm 7_Pre-monsoon

- Bhaluka_Farm 8_Pre-monsoon

- Bhaluka_Farm 9_Pre-monsoon

- Bhaluka_Farm 12_Post-monsoon

- Muktagacha_Farm 1_Pre-monsoon

- Muktagacha_Farm 2_Pre-monsoon

- Muktagacha_Farm 3_Pre-monsoon

- Muktagacha_Farm 10_Post-monsoon

- Trishal_Farm 4_Pre-monsoon

Trishal_Farm 5_Pre-monsoon

- Trishal_Farm 6_Pre-monsoon

- Trishal_Farm 11_Post-monsoon

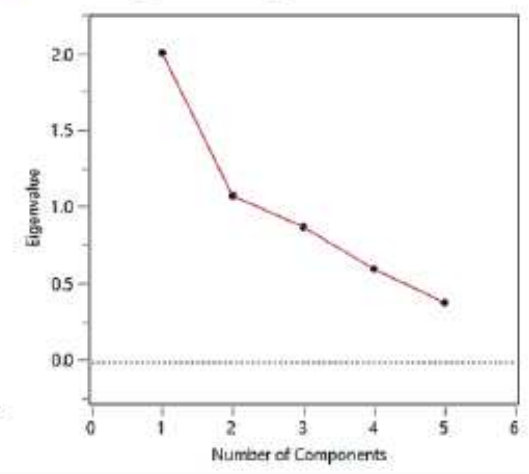

Figure 7

Biplot of tested heavy metals in pangas of studied areas by principal component analysis (PCA) where right-bottom corner of this figure displayed the scree plot of this PCA with two drastic slopes and eigen values. 
Muktagacha_Farm 1_Gill_Pre-monsoon Muktagacha_Farm 3_Gill_Pre-monsoon Bhaluka_Farm 7_Muscle_Pre-monsoon Muktagacha_Farm 2_Gill_Pre-monsoon Trishal_Farm 5_Gill_Pre-monsoon Bhaluka_Farm 9_Muscle_Pre-monsoon Bhaluka_Farm 7_Gill_Pre-monsoon Bhaluka_Farm 8_Muscle_Pre-monsoon Bhaluka_Farm 9_Gill_Pre-monsoon Muktagacha_Farm 2_Muscle_Pre-monsoon Trishal_Farm 6_Muscle_Pre-monsoon Trishal_Farm 4_Muscle_Pre-monsoon Trishal_Farm 6_Gill_Pre-monsoon Bhaluka_Farm 8_Gill_Pre-monsoon Muktagacha_Farm 3_Muscle_Pre-monsoon Trishal_Farm 6_Liver_Pre-monsoon Bhaluka_Farm 7_Liver_Pre-monsoon Bhaluka_Farm 8_Liver_Pre-monsoon Muktagacha_Farm 1_Liver_Pre-monsoon Muktagacha_Farm 2_Liver_Pre-monsoon Muktagacha_Farm 3_Liver_Pre-monsoon Bhaluka_Farm 9_Liver_Pre-monsoon Trishal_Farm 5_Muscle_Pre-monsoon Muktagacha_Farm 1_Muscle_Pre-monsoon Trishal_Farm 4_Gill_Pre-monsoon Trishal_Farm 4_Liver_Pre-monsoon Trishal_Farm 5_Liver_Pre-monsoon Muktagacha_Farm 10_Gill_Post-monsoon Muktagacha_Farm 10_Muscle_Post-monsoon Trishal_Farm 11_Liver_Post-monsoon Trishal_Farm 11_Muscle_Post-monsoon Muktagacha_Farm 10_Liver_Post-monsoon Bhaluka_Farm 12_Gill_Post-monsoon Bhaluka_Farm 12_Muscle_Post-monsoon Trishal_Farm 11_Gill_Post-monsoon Bhaluka_Farm 12_Liver_Post-monsoon

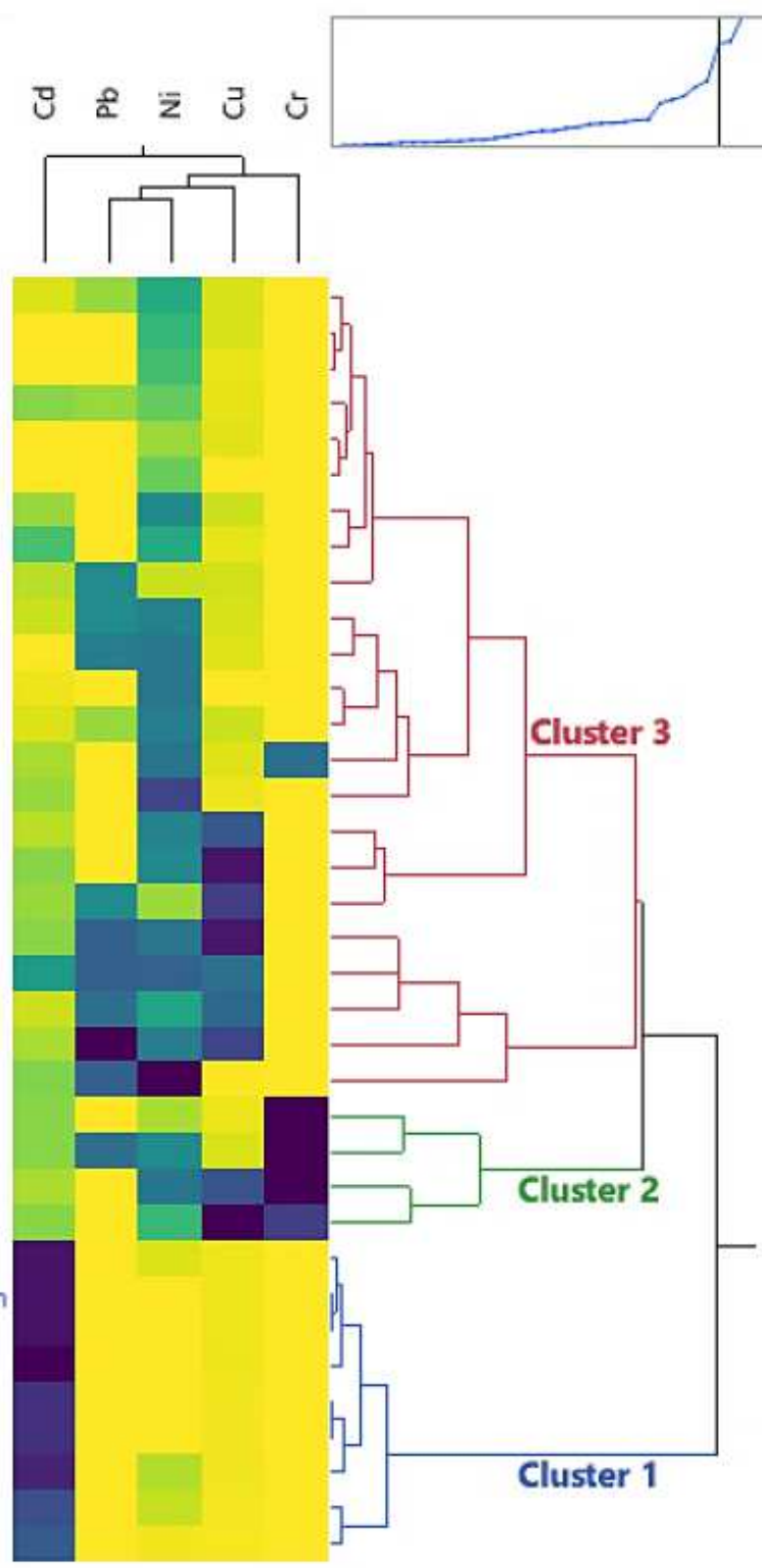

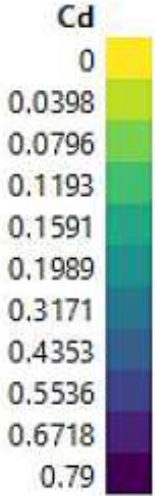

$\mathrm{Pb}$ 0.1082 0.2163 0.3245 0.4327 0.5408 1.4417 2.3425 3.2433 4.1442 5.045

$\mathrm{Ni}$

$\mathrm{Cu}$ 0.235

7.3311

14.662

21.993

29.324

36.656

64.727

92.799

120.87

148.94

177.02

$\mathrm{Cr}$

0
0.0063
0.0126

0.0126

0.0251

0.0314

0.0811

0.1308

0.1806

0.2303

0.28

\section{Figure 8}

Two-way cluster analysis of metal contents in pangas among sampling sites during pre and postmonsoon of 2017, where yellow color indicates the lowest concentrations of each metal and dark blue represents the highest concentrations. Color palette from yellow to dark blue represents increasing trends of metal concentrations. The rightmost corner of the figure indicates the distance graph that plotted distances beneath the dendrogram. Each farm with three values represents three tested tissue samples (gill, liver and muscle). 